\title{
MISIONES INTERIORES Y CAMBIO SOCIAL EN LA ESPAÑA DE FRANCO. UNA VISIÓN A TRAVÉS DE LA ACTIVIDAD MISIONERA DE LA ASESORÍA ECLESIÁSTICA DE SINDICATOS
}

\author{
POR \\ FRANCISCO BERNAL GARCíA ${ }^{1}$ \\ Universidad de Sevilla
}

\begin{abstract}
RESUMEN
El objetivo de este artículo es evaluar el impacto religioso y social de las misiones que la Asesoría Eclesiástica de Sindicatos llevó a cabo en España entre 1949 y 1972. Para ello, analizaremos cinco aspectos fundamentales. Primeramente, estudiaremos los esfuerzos realizados por los misioneros para localizar a personas no bautizadas o que no hubiesen recibido la primera comunión, con la finalidad de administrarles tales sacramentos. En segundo lugar, analizaremos el uso de las misiones como instrumento para lograr una restauración de la moral. En tercer lugar, expondremos las dificultades que el mensaje misional encontró para adaptarse a los cambios sociales y culturales derivados del crecimiento económico de la década de 1960. En cuarto lugar, subrayaremos los obstáculos que los misioneros encontraron para lograr que su mensaje fuera escuchado por la clase obrera y enfatizaremos la persistencia de fenómenos de «oposición a la misión». Y en quinto y último lugar, realizaremos una evaluación de los datos de asistencia a algunas misiones, como forma de determinar hasta qué punto éstas produjeron una verdadera recatolización. En conjunto, estos cinco aspectos pretenden constituir una aportación significativa al estudio de las misiones interiores en la España de la época de Franco.
\end{abstract}

PALABRAS CLAVE: misiones interiores; religión católica; España; régimen de Franco.

\section{INTERIOR MISSIONS AND SOCIAL CHANGE IN FRANCO'S SPAIN. A VISION THROUGH THE MISSIONARY ACTIVITY OF THE ASESORÍA ECLESIÁSTICA DE SINDICATOS}

\begin{abstract}
The aim of this article is to assess the religious and social impact of the missions that the Asesoría Eclesiástica de Sindicatos carried out in Spain from 1949 until 1972. To that end, we will focus on five key aspects. Firstly, we will study the missionaries' effort to find people who had not been baptized or who had not made their First Communion, with the intention of administering them those sacraments. Secondly, we will analyse the use of the missions as an instrument for the restoration of morality. In third place, we will expose the difficulties that the missionaries' message found to adapt itself to the social and cultural changes derived from the 1960s economic growth. In fourth place, we will underline the obstacles that the missionaries found to get their message heard by the working class and we will emphasize the persistence of cases of «opposition to the mission». And finally, we will assess the data of attendance to some missions, in order to discuss to what extent they produced an effective re-Catholicization. On the whole, these five aspects intend to make a significant contribution to the study of interior missions in Spain during the Franco regime.
\end{abstract}

KEY WORDS: Interior missions; Catholic religion; Spain; Franco Regime.

CÓMO CITAR ESTE ARTículo / CITATION: Bernal García, F. 2018. «Misiones interiores y cambio social en la España de Franco. Una visión a través de la actividad misionera de la Asesoría Eclesiástica de Sindicatos». Hispania Sacra 70, 141: 339-363. https://doi. org/10.3989/hs.2018.025

Recibido/Received 08-02-2016

Aceptado/Accepted 16-02-2016

${ }^{1}$ fbernal@us.es / ORCID iD: http://orcid.org/0000-0003-4327-9155 
INTRODUCCIÓN. LA LABOR MISIONERA DE LA ASESORÍA ECLESIÁSTICA DE SINDICATOS

Finalizada la Guerra Civil, el episcopado español puso en marcha un ambicioso proyecto destinado a restablecer la unanimidad religiosa de la sociedad española y a bloquear el proceso de secularización que se había visto acelerado por las políticas laicistas desplegadas durante la II República. Uno de los instrumentos más destacados de ese proyecto de restauración fueron las misiones, conocidas en la terminología eclesiástica como «misiones interiores»o "populares». Durante un congreso de misioneros celebrado en el Santuario de Loyola en 1956 las mismas fueron definidas como:

Actos extraordinarios del apostolado de la Iglesia, realizados por Sacerdotes especializados, enviados a los fieles de una o varias Parroquias por el Obispo y los Superiores de la Comunidad, para promover la salvación y la santificación de los pueblos, por medio de la predicación, de los Sacramentos y de la oración colectiva.

Y los objetivos que se les atribuían quedaban explicados del siguiente modo: «llegar con eficacia salvadora a todas las clases sociales; producir en todas una conversión sincera y consciente; y dejar en todas esperanzas fundadas de perseverancia». ${ }^{2}$

Las primeras misiones del período franquista se llevaron a cabo pocos meses después de la terminación de la contienda civil y tenían como principal objetivo llevar el mensaje católico a zonas de poblamiento disperso, donde tradicionalmente habían existido dificultades para que la Iglesia estableciese un contacto permanente con la población. De una manera especial, se deseaba visitar localidades rurales que habían permanecido en zona republicana durante la guerra y en las que, una vez finalizada la misma, la vida eclesiástica no se encontraba aún restablecida debido a que no contaban con párroco o a que el templo parroquial había sido destruido. Realizar misiones en estas localidades era considerado como algo urgente, ya que durante el tiempo en que habían permanecido en el bando republicano habían proliferado entre sus habitantes las situaciones irregulares desde el punto de vista eclesiástico, tales como niños que no habían sido bautizados al nacer o parejas que habían comenzado a convivir sin estar casadas. ${ }^{3}$

Sin embargo, ya desde 1941 estos primeros esfuerzos aislados van a verse insertos en una estrategia global. Los prelados de las distintas diócesis van a elaborar «planes misionales» que, a menudo, contemplarán la realización de misiones en todas las localidades sometidas a su jurisdicción, así como la repetición de las mismas cada tres o cuatro años. ${ }^{4}$

2 Congreso 1957: 78 y 93. Por su parte, el jesuita Ginés Muñoz las definía como: «El medio extraordinario de la Iglesia y el más eficaz para conservar y aumentar la fe y salvar las almas. Y consiste en un conjunto de sermones, instrucciones, avisos, procesiones, actos espectaculares, penitencias, industrias y cánticos, puestos en juego con la mayor eficacia y fervor para instruir y renovar en los pueblos la fe de nuestra Sacrosanta Religión. Todo ello informado con la gracia divina, que a torrentes derrama el Cielo en la Santa Misión»: Muñoz 1947: 82-83.

3 Un ejemplo de este tipo de misiones iniciales lo encontramos en las campañas organizadas por la Compañía de Jesús en Andalucía a partir de 1940; véase: Copado 1973.

4 Callahan 2002: 360-365.
No se trataba ya solamente de llegar a zonas donde el clero era escaso o donde la persecución religiosa republicana había dejado maltrechas las estructuras eclesiásticas, sino que se aspiraba a llevar el mensaje misional a todos.

La implementación de estos "planes misionales» se tradujo en un clima de movilización religiosa que habría de prolongarse durante toda la década de 1940. Ciudades y pueblos se convirtieron en escenario habitual de manifestaciones multitudinarias. Los vía crucis celebrados en medio de la noche a la luz de antorchas portadas por filas de penitentes; las predicaciones de misioneros en la vía pública; las largas filas de devotos frente a confesionarios instalados en plena calle; o las misas de campaña celebradas en la plaza principal y que se saldaban con comuniones masivas, crearon un ambiente triunfalista que llevó a muchos eclesiásticos a pensar que la secularización estaba siendo derrotada y que la sociedad española volvía a estar unida en torno a la fe católica.

Las misiones interiores conservaron su vigor en la década de 1950. Los intentos de algunos misioneros por modernizar sus técnicas y contenidos chocaron con la opinión mayoritaria de las órdenes religiosas, partidarias de la misión tradicional, basada en actos espectaculares y en una fuerte movilización en la vía pública. ${ }^{5}$ Con la llegada de la década de 1960 sí podemos hablar ya de una crisis de las misiones interiores. El impacto del Concilio Vaticano II hizo que numerosos clérigos y algunos prelados cuestionasen una técnica de comunicación religiosa que no encajaba con el modelo de evangelización dialogante y sensible a las problemáticas sociales que era preconizado ahora desde Roma. Al mismo tiempo, las misiones empezaron a chocar con la incipiente formación de una cultura consumista a que el crecimiento económico experimentado por el país desde comienzos de la década estaba dando lugar y con la cual el mensaje misional -que hacía hincapié en ideas tales como pecado, sacrificio y redención - tenía escasas posibilidades de adecuación. No obstante, ello no quiere decir que las misiones desapareciesen. Muy al contrario, siguieron llevándose a cabo durante toda la década de 1960 e, incluso, durante los años iniciales de la de 1970 y aunque con el paso del tiempo perdieron espectacularidad, conservaron una capacidad de movilización en absoluto despreciable. ${ }^{6}$

5 El debate entre los partidarios de renovar la técnica misional y aquellos que se aferraban al modelo tradicional puede ser seguido en: Congreso 1961. Las órdenes religiosas españolas que realizaban misiones mostraron cierta capacidad para modernizar los instrumentos que utilizaban en el desarrollo de las mismas, incorporando elementos tales como la radiofonía o la publicidad, pero no así para modernizar su contenido. Los misioneros españoles eran conscientes de que la misión tradicional estaba siendo cuestionada en otros países europeos, donde se apostaba por métodos renovados de comunicación religiosa, menos espectaculares en cuanto a las formas y de mayor contenido social, pero se resistían a abandonar un paradigma que consideraban que, al menos en España, seguía dando resultados.

6 En muchos sentidos, podemos observar una evolución parecida en otros países católicos. En Francia, por ejemplo, las misiones interiores experimentaron un importante revival tras la II Guerra Mundial que se prolongaría durante toda la década de 1950 para caer en una abrupta crisis durante la década posterior. Hay, sin embargo, importantes diferencias entre los casos español y francés. En Francia, el movimiento de las misiones interiores, impulsado por el Centre Pastoral des Missions à I'Intérieur (CPMI), estuvo abierto desde un principio a la incorporación de metodologías novedosas, como la introducción de la «cuestión 
Las misiones ocupan, por lo tanto, un lugar destacado en la historia religiosa del período franquista, siquiera sea porque, debido al amplio número de localidades en que se realizaron y a su reiteración en el tiempo, un importante número de españoles las experimentó en algún momento de sus vidas. Constituyeron un instrumento privilegiado por la jerarquía eclesiástica en su proyecto de resocializar a la población española en los valores católicos, en aras de lograr una sociedad en la que la identificación con los mismos fuese unánime y en la que la Iglesia constituyese una referencia cultural indiscutible. Esta importancia contrasta con la escasa atención que han recibido por parte de la historiografía, siendo escasos los trabajos que las han tenido en cuenta y aún menos los que se les han dedicado desde una perspectiva monográfica. ${ }^{7}$

En un trabajo anterior realicé un estudio de la estructura organizativa de las misiones celebradas durante la época de Franco, describiendo los actos que las componían y analizando los objetivos que perseguían. ${ }^{8}$ En esta nueva aportación pretendo centrarme en las consecuencias religiosas y sociales de la actividad misional. Es decir, voy a evaluar en qué medida las misiones transformaban la vida religiosa y social de las localidades donde se celebraban. Ello me permitirá abordar la cuestión de si las misiones constituyeron un instrumento eficaz a la hora de frenar el proceso de secularización y restaurar la unanimidad de la sociedad española en torno a la fe católica.

Para llevar a cabo este estudio me centraré en una de las instituciones que más activamente participó en el movimiento misional del período franquista: la Asesoría Eclesiástica de Sindicatos, organismo creado en 1944 con la finalidad de prestar asistencia religiosa a la Organización Sindical. Tres fueron las actividades en las que, principalmente, concentró sus esfuerzos esta Asesoría: la realización de tandas de ejercicios espirituales dirigidas a obreros y a empleados de la propia Organización Sindical; el desarrollo de programas de información y formación religiosa destinados a ser desarrollados en el interior de los centros de trabajo (destacando entre ellos la campaña denominada "La Voz de Cristo en las Empresas»); y la organización y ejecución de misiones interiores. ${ }^{9}$

En la Tabla 1 he sintetizado las principales cifras relativas a las misiones organizadas por ella. No obstante, hemos de tener en cuenta que las mismas no reflejan la totalidad de su actividad, dado que, además de organizar sus propias misiones, la Asesoría también colaboraba en la ejecución de otras que habían sido organizadas por los obispos de las distintas diócesis o por otras instituciones religiosas.

social» en el temario misional o los intentos de los misioneros de implicarse en las comunidades misionadas, conviviendo durante largos períodos con ellas. En España, por el contrario, hubo una fuerte pervivencia del modelo tradicional de misión, caracterizado por actos públicos altamente espectaculares que se desarrollaban durante un número limitado de días. Véase: Cavalin y Viet-Depaule 2009: 9-41.

7 En la década de 1970 algunos sociólogos realizaron aproximaciones: Orensanz 1974: 9-22; Urbina 1977: 11-20. Ya desde un punto de vista historiográfico: Callahan 1987: 491-503; Ruiz Sánchez 1998: 275326; Alfonsi 1999a: 119-134; Verdoy Herranz 2015: 99-113. Con una perspectiva cronológica de larga duración, pero incluyendo también la época de Franco: Cabada Castro 2015.

8 Bernal García 2015: 227-253.

9 Sobre la Asesoría: López Gallego 2004: 661-686; Bernal García 2010: 191-195.
TABLA 1

Misiones organizadas por la Asesoría Eclesiástica de Sindicatos, 1949-1972

\begin{tabular}{|c|c|c|c|c|}
\hline Año & $\begin{array}{l}\text { Campañas } \\
\text { realizadas }\end{array}$ & $\begin{array}{l}\text { Localidades } \\
\text { misionadas }\end{array}$ & $\begin{array}{l}\text { Población } \\
\text { misionada }\end{array}$ & Provincias \\
\hline 1949 & 6 & 70 & 120.000 & $\begin{array}{l}\text { León, Murcia, Palencia, } \\
\text { Teruel, Zaragoza }\end{array}$ \\
\hline 1950 & 14 & 123 & 81.857 & $\begin{array}{l}\text { Alicante, Almería, Asturias, } \\
\text { Cáceres, Ciudad Real, Cuenca, } \\
\text { Gerona, Guadalajara, León, } \\
\text { Murcia, Navarra, Palencia, } \\
\text { Teruel }\end{array}$ \\
\hline 1951 & 7 & 65 & 89.000 & $\begin{array}{l}\text { Albacete, Asturias, Gerona, } \\
\text { Murcia, Tenerife }\end{array}$ \\
\hline 1952 & 4 & 34 & 50.000 & $\begin{array}{l}\text { Cáceres, Huesca, Logroño, } \\
\text { Santander }\end{array}$ \\
\hline 1953 & 4 & 8 & 16.000 & Ávila, Cuenca, Lugo, Teruel \\
\hline 1954 & 1 & 1 & 4.000 & Gerona \\
\hline 1955 & 3 & 17 & 25.000 & Gerona, León, Teruel \\
\hline 1956 & 4 & 82 & 53.707 & Huelva, Islas Baleares, León \\
\hline 1957 & 0 & 0 & 0 & \\
\hline 1958 & 1 & 46 & 30.000 & Palencia \\
\hline 1959 & 4 & 178 & 100.000 & $\begin{array}{l}\text { Asturias, León, Navarra, } \\
\text { Santander }\end{array}$ \\
\hline 1960 & 4 & 93 & 210.000 & La Coruña, Lugo, Santander \\
\hline 1961 & 4 & 50 & 125.000 & $\begin{array}{l}\text { Almería, Ciudad Real, Lugo, } \\
\text { Murcia }\end{array}$ \\
\hline 1962 & 1 & 42 & 25.000 & Lugo \\
\hline 1963 & 1 & 164 & 600.272 & La Coruña, Lugo, Pontevedra \\
\hline 1964 & 2 & 10 & 38.148 & Córdoba, Mallorca \\
\hline 1965 & 2 & 29 & 17.138 & Ávila, Huesca \\
\hline 1966 & 2 & 67 & 45.000 & Ávila, Cáceres \\
\hline 1967 & 4 & 56 & 31.316 & $\begin{array}{l}\text { Almería, Huesca, Palencia, } \\
\text { Zamora }\end{array}$ \\
\hline 1968 & 2 & 50 & 70.000 & Almería, Cáceres \\
\hline 1969 & 3 & 37 & 30.144 & Almería, Teruel, Zamora \\
\hline 1970 & 1 & 24 & 16.938 & Zamora \\
\hline 1971 & 1 & 10 & 3.299 & Zamora \\
\hline 1972 & 2 & 22 & 43.727 & Jaén, Zamora \\
\hline TOTAL & 77 & 1.278 & 1.825 .546 & \\
\hline
\end{tabular}

Fuente: Elaboración propia a partir del Boletín de Información de la Asesoría Eclesiástica de Sindicatos y de documentación del Archivo General de la Administración (AGA).

A lo largo de sus veinticuatro años de actividad, los misioneros de la Asesoría visitaron 1.278 localidades y llevaron su mensaje a más de un millón ochocientas mil almas, realizando la que, muy probablemente, fue la aportación singular más destacada al movimiento de las misiones interiores durante la época de Franco. Como puede observarse, la distribución en el tiempo de ese esfuerzo no fue homogénea. El fuerte impulso observado en 1949 y durante los dos primeros años de la década de 1950 se fue desinflando a partir de 1952, experimentando mínimos en 1954, cuando sólo fue misionada la localidad de Llagostera (Gerona) y en 1957, año en que no se organizó ninguna misión. Estas caídas en la actividad fueron consecuencia de los problemas económicos que sufrió la Organización Sindical en aquellos años, los cuales le llevaron a reducir drásticamente la asignación presupuestaria de la Asesoría.

Sin embargo entre finales de la década de 1950 y 
comienzos de la de 1960, ya con las finanzas sindicales restablecidas, la actividad experimentó un fortísimo avance, viviendo sus picos máximos entre 1960 y 1963, período en que se llevó a cabo la denominada "Misión Marinera de la Costa de Galicia», que afectó a los principales pueblos costeros gallegos. La apoteosis vivida durante esos años no volvió a repetirse, pero aun así se mantuvo una actividad estimable durante el resto de la década.

La Asesoría entró en la década de 1970 en una situación de dificultad debido a su fuerte cuestionamiento desde las propias instancias eclesiásticas: la Asamblea Conjunta de Obispos y Sacerdotes celebrada en 1971 aprobó una Proposición en la que se pedía su disolución, por considerarla incompatible con la libertad sindical. ${ }^{10}$ Aun así, en 1972, un año antes del cese brusco de su actividad, la Asesoría fue capaz de llevar su mensaje a más de 40.000 almas, demostrando que su ímpetu misionero estaba lejos de estar agotado.

UN SOLO PUEBLO, UNA SOLA FE: BAUTIZOS Y PRIMERAS COMUNIONES

Cuando los misioneros visitaban una localidad pretendían dejar tras de sí una comunidad en la que sus miembros hubiesen quedado unánimemente comprometidos con la religión católica. La misión no contemplaba excepciones y cuando éstas se producían se consideraba que la misma no había alcanzado plenamente sus objetivos. El ideal era el de una sociedad articulada en torno a una fe común, indiscutida, en la que el ámbito de lo sagrado vertebrase todas las relaciones sociales.

La primera manifestación de esta voluntad totalizadora va a ser el afán de los misioneros por localizar a personas que no hubiesen recibido el sacramento del bautismo y proceder a administrárselo. Era lógico que así fuese: si los misioneros aspiraban a restaurar una comunidad católica sin fisuras, lo primero que debían hacer era convertir en miembros de la Iglesia a aquellos que, por no haber sido bautizados, aún no lo eran. Entre los bautizos realizados durante las misiones debemos distinguir dos tipos: los "bautizos retrasados» y los "bautizos de adultos». Los primeros eran administrados a niños que, en contra de la recomendación eclesiástica, no habían sido cristianados en el momento de su nacimiento, mientras que los segundos eran administrados a individuos que habían alcanzado la edad adulta sin haber sido cristianados.

Tradicionalmente, la sociología católica había considerado que el número de los no bautizados en España era ínfimo, dado que el bautismo constituía un rito profunda-

10 Concretamente, la Proposición número 47 de la Primera Ponencia aprobada por la Asamblea rezaba: «Asimismo deben suprimirse o modificarse sustancialmente, las capellanías y asesorías religiosas de organismos oficiales, en que los sacerdotes no pueden realizar su cometido con la libertad y eficacia requeridas. Este planteamiento aparece más urgente en las asesorías religiosas de sindicatos»; véase: Secretariado Nacional del Clero 1971: 173. La Asesoría reaccionó enviando una carta de protesta a la Conferencia Episcopal Española, en la que aseguraba haber realizado su cometido "con total libertad" y en la que justificaba su existencia esgrimiendo, entre otros aspectos, la intensa labor misionera realizada: Archivo General de la Administración (AGA), Asesoría Eclesiástica de Sindicatos (AES), 1971, Caja 10. mente arraigado en la sociedad, una especie de obligación de los padres hacia los hijos que aquéllos cumplían independientemente de la intensidad de sus creencias religiosas. ${ }^{11}$ Pero lo cierto es que tanto los bautizos retrasados como los de adultos se repitieron con frecuencia en las misiones celebradas en las décadas de 1940 y 1950.

En primer lugar, durante los años posteriores a la Guerra Civil se produjo una avalancha de bautizos retrasados, correspondientes en su mayoría a niños que habían nacido en zona republicana durante la contienda y que, independientemente de las creencias religiosas de sus padres, no habían podido recibir el sacramento, debido a que la actividad eclesiástica había quedado virulentamente suspendida. ${ }^{12}$ Se produjeron también en estos momentos bautizos de niños que habían nacido durante el período republicano, con anterioridad al estallido de la contienda, y que no habían sido bautizados, presumiblemente debido a una decisión deliberada de sus padres, influidos por el clima anticlerical promovido por las fuerzas de izquierdas en aquellos años. ${ }^{13}$ En cualquier caso, el problema de los no bautizados que se había generado durante la II República y, sobre todo, durante la Guerra Civil no pudo ser resuelto por la Iglesia de una manera inmediata, prolongándose durante buena parte de la década de 1940. El clero había quedado diezmado por la represión republicana y la iconoclastia anticlerical había dejado inservibles los templos parroquiales en numerosas localidades. En este contexto, las misiones, debido a su carácter itinerante, se convirtieron en el instrumento ideal para lograr la recatolización de aquellos sectores que se habían visto más afectados por la política laicista republicana.

Pese a no comenzar a realizar misiones hasta 1949, la Asesoría Eclesiástica de Sindicatos colaboró desde sus inicios en el esfuerzo por localizar a población no bautizada. ${ }^{14}$ Cuando puso en marcha sus propias misiones, la actividad bautismal siguió formando parte de sus preocupaciones, si bien es cierto que en las crónicas de sus misioneros se va a hablar más de bautizos de adultos que de bautizos retrasados. El fenómeno de los adultos no bautizados parecía poseer especial relevancia en las Islas Canarias. En 1950 el Asesor Eclesiástico de Santa Cruz de Tenerife

11 Así lo puso de relieve una encuesta realizada en 1936, en pleno apogeo de la ofensiva laicista republicana: Montero 2002: 189-203. También: Moreno Seco 2002: 433-445.

12 Ciertamente, el Código de Derecho Canónico autorizaba $-\mathrm{y}$ autoriza - a cualquier persona a bautizar en ausencia de un ministro autorizado. Posteriormente, si surgían dudas acerca de la correcta administración del sacramento, la situación podría normalizarse a través de un bautizo sub conditione. Es probable que algunas familias católicas recurriesen a esta posibilidad. Sin embargo, los autores de una recopilación de historias orales de la Guerra Civil nos señalan que son escasos los casos de este tipo que han encontrado; véase: Bullón de Mendoza y De Diego 2000: 218-219. No está claro tampoco que esta posibilidad fuese conocida ampliamente entre la población rural perteneciente a los estratos socio-económicos más bajos. Así, durante los primeros años de la década de 1940 los jesuitas llevaron a cabo una intensa actividad bautismal en territorios de Málaga, Jaén, Granada y Almería que habían formado parte de la zona republicana durante la guerra y en ningún momento se nos dice que se tratase de bautizos sub conditione; véase: Copado 1973: 13 y ss.

13 En este sentido: Barrios Rozúa 1999: 179-224.

14 Así, la Asesoría Provincial de Jaén dedicó el curso de 1945-1946 a esta labor, logrando llevar a cabo 204 bautizos: Asesoría Eclesiástica Nacional de Sindicatos 1946: 76. 
aseguraba que en dicha diócesis eran escasas las parroquias en cuyo entorno no vivían varias decenas de adultos sin bautizar. ${ }^{15}$ Como consecuencia de ello, los bautizos fueron constantes en las misiones que la Asesoría llevó a cabo en las islas de Tenerife y La Palma durante el año de $1951 .{ }^{16}$ También habían sido un componente destacado de la misión celebrada un año antes en la zona de canteras cercana a las localidades almerienses de Olula del Río y Macael. ${ }^{17} \mathrm{Y}$ todavía en 1961 jugaron un papel de cierta relevancia en la celebrada en la cuenca minera de La Unión, en la provincia de Murcia. ${ }^{18}$

Resulta difícil determinar qué condicionantes religiosos o sociales habían llevado a estas personas a llegar hasta la edad adulta sin estar bautizados en el contexto de una sociedad donde la inmensa mayoría sí lo estaba. Las fuentes de la Asesoría son elusivas al respecto: los misioneros se ufanaban de haber incorporado nuevos miembros a la Iglesia, pero no proporcionaban detalles sobre los motivos que habían llevado a estas personas a no estar bautizadas. Una posible explicación podría vincular este tipo de comportamientos a actitudes de tipo anticlerical e irreligioso. Pero hay otro factor que debe ser tenido en cuenta: prácticamente todos los adultos bautizados durante las misiones tenían en común unas pobres condiciones de vida $y$, presumiblemente, un bajo nivel educativo. De los trabajadores de canteras bautizados durante las misiones en Olula del Río y Macael se nos decía que «carecían de calzado y vestían ropa hecha un puro girón $» .{ }^{19}$ Por su parte, los obreros bautizados en La Unión eran presentados como "pobres o muy pobres», si bien también se apuntaba que procedían de un ambiente de "indiferencia e ignorancia religiosa». ${ }^{20}$ Una cosa parece cierta: en la España de la década de 1950 llegar a la edad adulta sin estar bautizado era sinónimo de un muy bajo nivel económico y cultural. ¿Qué había pesado más en el apartamiento de la Iglesia por parte de estas personas, una irreligiosidad consciente o una situación de exclusión social? Las fuentes no nos permiten abordar con garantías esta cuestión. ${ }^{21}$

Lo que sí resulta patente es que a medida que nos adentramos en la década de 1960 las noticias de bautizos acaecidos durante las misiones, tanto de adultos como retrasados, se van haciendo cada vez más esporádicas, hasta desaparecer. Ello revelaría un evidente éxito de los eclesiásticos a la hora de poner fin a las bolsas de adultos no

\footnotetext{
15 AGA, AES, 1950, Caja 25.

16 Boletín de Información de la Asesoría Eclesiástica de Sindicatos, no 9, 1952.

17 Boletín de Información..., no 4, 1950.

18 Boletín de Información..., no 49, 1962.

19 Boletín de Información..., no 4, 1950.

20 AGA, AES, 1961, Caja 23-3.

21 Indudablemente, las situaciones de exclusión social podían ser también compatibles con el mantenimiento de ideologías anticlericales. Así, por ejemplo, en la década de 1940 el Boletín Oficial del Obispado de Madrid conceptuaba a la población más desfavorecida de los suburbios de la capital como profundamente ignorante en materia religiosa y, al mismo tiempo, animada por un inequívoco odio hacia el clero; véase: Andrés-Gallego 2013: 248-252. Del mismo modo, en 1949 el jesuita Florentino del Valle señalaba que en los barrios deprimidos del extrarradio de Madrid se daban casos de familias pobres que no bautizaban a sus hijos, alegando "que no había iglesia» o que «les habían dicho que costaba dinero», excusas éstas tras la que creía ver un innegable poso antirreligioso: Del Valle 1949: 99-124.
}

bautizados que quedaban en España, así como de normalizar la práctica del bautismo temprano. Resulta indudable que la labor de los misioneros había resultado fundamental para que esta cruzada llegase a buen puerto.

$\mathrm{Si}$ el bautismo es el sacramento que permite formar parte de la Iglesia, la comunión, al proporcionar acceso a la eucaristía, es el que liga al individuo con aquélla. Debido a ello, los misioneros ponían especial empeño en localizar a adultos que no hubieran recibido la primera comunión y en convencerlos para que aceptasen recibirla. Este grupo de adultos era singularmente más numeroso que el de los no bautizados: en las décadas de 1940 y 1950 existía todo un sector de la población española cuya relación con los sacramentos había finalizado con el bautismo. Resulta imposible ofrecer datos numéricos, pero la reiteración con que las primeras comuniones de adultos se suceden en las misiones realizadas a lo largo de dichas décadas nos muestra que se trataba de una parte de la población minoritaria, pero no insignificante. En 1950 en la isla de Tabarca, cercana al puerto de Alicante, los misioneros de la Asesoría organizaron la primera comunión de los niños pero, al comprobar que buena parte de los adultos que habitaban la isla no la habían realizado, debieron incluir a éstos en la ceremonia. En este caso, se repite el ambiente de pobreza que ya señalamos anteriormente: la Asesoría tuvo que proporcionar ropas a buena parte de los comulgantes para que el acto pudiera desenvolverse con «decoro».22 En 1951, durante la misión realizada en las minas de Osor (Gerona) un nutrido grupo de jóvenes mineros, con edades comprendidas entre los 23 y los 27 años y en su mayoría inmigrantes procedentes de la provincia de Murcia, recibió la primera comunión. ${ }^{23} \mathrm{Y}$ en 1961, durante los actos misionales organizados por la Asesoría en la cuenca minera de La Unión (Murcia) las primeras comuniones de adultos fueron también frecuentes, siendo protagonizadas en algunos casos por personas con más de 50 años de edad. ${ }^{24}$

Al igual que ocurre con los no bautizados, las fuentes misionales no nos ofrecen información precisa sobre los condicionantes que habían llevado a estos adultos a no realizar la primera comunión. Indirectamente, sí podemos llegar a la conclusión de que, muy posiblemente, todos ellos tenían en común no haber sido escolarizados. Existía un vínculo directo entre escolarización y realización de la primera comunión. El motivo es que, dejando al margen el breve período laicista de la II República, el sistema escolar español se había caracterizado por su fuerte contenido religioso: los maestros y maestras velaban porque los niños aprendiesen el catecismo y realizasen la primera comunión. Esta tradicional simbiosis entre Iglesia y escuela no había hecho sino reforzarse tras la Guerra Civil. Los misioneros atribuían un enorme valor al papel de los maestros, no sólo para lograr la movilización de niños y familiares durante las misiones, sino también a la hora de mantener viva la llama de la fe entre la infancia durante el resto del año. En 1959 en Abadengo de Torío (León) la maestra se comprometió con el misionero a llevar a los niños a la iglesia una vez por semana, para que las enseñanzas que habían recibido

\footnotetext{
22 AGA, AES, 1950, Caja 25.

23 Boletín de Información..., n으 7, 1951.

24 Boletín de Información..., no 49, 1962.
} 
TABLA 2

Tasa de escolarización y actitudes religiosas en tres comarcas misionadas por la Asesoría Eclesiástica de Sindicatos

\begin{tabular}{|c|c|c|c|c|c|}
\hline Campaña misional & Fecha & $\begin{array}{l}\text { Población } \\
\text { misionada }\end{array}$ & $\begin{array}{l}\text { Tasa de escolarización } \\
\text { 6-14 años (\%) }\end{array}$ & $\begin{array}{l}\text { Cumplimiento dominical } \\
\qquad(\%)\end{array}$ & Cumplimiento pascual (\%) \\
\hline Cuenca minera de Peñarroya-Pueblonuevo (Córdoba) & 1964 & 35.148 & 63,1 & 37,5 & 44,5 \\
\hline Valles de los ríos Alberche y Tiétar (Ávila) & 1965 & 15.838 & 97,5 & 70,8 & 84,8 \\
\hline Tierra de Campos (Zamora) & 1967 & 11.737 & 100,0 & 90,2 & 93,7 \\
\hline
\end{tabular}

Fuente: Elaboración propia a partir de documentación del AGA $^{29}$

durante la misión no cayesen en el olvido. ${ }^{25}$ En 1967 en Las Negras, pedanía de Níjar (Almería) que no poseía capilla, la maestra era la autoridad eclesiástica «de facto»: enseñaba el catecismo a los niños y los días de fiesta los llevaba a oír misa en la vecina localidad de Rodalquilar. ${ }^{26}$ Por el contrario, en 1961 la «desastrosa situación religiosa» de la parroquia de San Roque, en la ciudad de Almería, la cual quedaba plasmada en bajos índices de asistencia a misa y numerosos "amancebamientos» y «noviazgos prematuros», era achacada al hecho de que los maestros no residiesen en el barrio y no hubiesen mostrado nunca compromiso alguno con su vida religiosa. ${ }^{27}$

Resulta comprensible, por lo tanto, que los misioneros fuesen grandes entusiastas de la escolarización. Las crónicas misionales de la década de 1940 contenían frecuentes quejas en el sentido de que el alto porcentaje de población infantil que no asistía a la escuela dificultaba el proyecto de recatolización que se pretendía llevar a cabo: un niño no escolarizado era mucho menos propenso a convertirse en un católico practicante al llegar a adulto que otro que sí lo estaba.

Los avances experimentados por la escolarización durante las décadas de 1950 y 1960 contribuyeron a fortalecer la posición social de la Iglesia, dado que los niños eran escolarizados en una escuela católica. No obstante, este proceso de escolarización distó de ser completo. En el curso 1959-1960 se estimaba que más de 350.000 niños en edad de escolarización obligatoria - de 6 a 12 años - no estaban escolarizados, lo cual venía a suponer un $11,2 \%$ del total. La tasa de escolarización presentaba, además, grandes divergencias regionales: mientras 18 provincias -Álava, Ávila, Baleares, Burgos, Gerona, Guadalajara, Guipúzcoa, León, Logroño, Navarra, Palencia, Salamanca, Segovia, Soria, Valladolid, Vizcaya, Zamora y Zaragozapresentaban valores muy cercanos a la plena escolarización, un grupo de 8 provincias, todas ubicadas en el sur del país -Badajoz, Cádiz, Córdoba, Granada, Jaén, Málaga, Sevilla, Tenerife- presentaban tasas inferiores al $70 \%{ }^{28}$

25 AGA, AES, 1959, Caja 23-3.

26 AGA, AES, 1967, Caja 23-1.

27 AGA, AES, 1961, Caja 23-3.

28 Cáritas Española 1965: t. I, 89-117. Cáritas proporcionaba estos datos con la finalidad de resaltar las insuficiencias que presentaba el sistema educativo español. A pesar de ello, es posible que los mismos contuviesen un involuntario sesgo al alza. El propio informe de Cáritas alertaba de que, entre los alumnos matriculados, existía un grave problema de absentismo escolar crónico que se estimaba en torno a un $12 \%$. Clara Eugenia Núñez sitúa la tasa de escolarización de España en 1960
No sorprendentemente, las provincias que presentaban tasas más bajas de escolarización eran también las que presentaban índices de práctica religiosa más bajos, observándose el fenómeno opuesto en las provincias de alta escolarización.

Por lo demás, la vinculación entre escolarización y práctica religiosa es plenamente observable en las misiones de la Asesoría. La Tabla 2 nos muestra la relación existente entre la tasa de escolarización y las actitudes religiosas en tres comarcas misionadas.

En Tierra de Campos y en los valles de los ríos Alberche y Tiétar, donde la escolarización en la enseñanza primaria era prácticamente universal, los índices de cumplimiento dominical y pascual eran muy altos, revelando unas sociedades donde la religión católica era el elemento articulador de la vida colectiva. Por el contrario, en la cuenca minera de Peñarroya-Pueblonuevo, donde la tasa de escolarización estaba entre las más bajas de España, los índices de cumplimiento dominical y pascual no llegaban al $50 \%$, poniendo en evidencia una sociedad en la que el catolicismo articulaba la vida de un sector importante, pero no mayoritario, de la misma.

\section{LAS MISIONES COMO INSTRUMENTO DE RESTAURACIÓN MORAL}

El proyecto de resocialización de la población española que la jerarquía eclesiástica inició tras la Guerra Civil poseía una fuerte dimensión moralizante. No se trataba sólo de que la población estuviese bautizada, recibiese la primera comunión y acudiese regularmente a misa; se trataba también de que su vida privada se ajustase a los códigos

en un $75 \%$, pero la calcula sobre la población de 5 a 14 años, cuando en aquel momento la obligatoriedad abarcaba sólo de los 6 a 12 años, siendo en 1964 cuando se prolongó hasta los 14 años: Núñez 2005: 210.

${ }_{29}$ Municipios misionados en Córdoba: Peñarroya-Pueblonuevo, La Granjuela, Valsequillo, Los Blázquez, Belmez; Villanueva del Rey. Municipios misionados en Ávila: Burgohondo; Cardeñosa, Casavieja; Casillas; Cebreros, Gavilanes; Herradón de Pinares; Hoyo de Pinares; Lanzahíta; Mijares; Muñana; Navalperal de Pinares; Navarredondilla; Las Navas del Marqués; Navatalgordo; Niharra; Peguerinos; Piedralaves; Salobral; S. Bartolomé de Pinares; S. Juan del Molinillo; Sta. Cruz de Pinares; Sta. María del Tiétar; Sotalbo; Sotillo de la Adrada; El Tiemblo; Villatoro. Municipios misionados en Zamora: Cañizo de Campos; Castrogonzalo; Castroverde de Campos; Cotanes del Monte; Prado; Fuentes de Ropel; Quintanilla del Olmo; Revellinos de Campos; S. Agustín del Pozo; S. Esteban del Molar; S. Miguel del Valle; Tapioles de Campos; Vidayanes; Villalobos; Villamayor de Campos; Villanueva del Campo; Villar de Fallaves; Villarrín de Campos. 
morales marcados por la Iglesia. Sin una vida moral no podía existir verdadera religiosidad y sin moralización no podía existir recatolización. ${ }^{30}$ Una vez más, las misiones fueron escogidas como uno de los instrumentos preferidos para lograr este objetivo.

Los misioneros de comienzos de la década de 1940 poseían una visión pesimista de la situación moral de la sociedad española. Consideraban que el período histórico inmediatamente anterior -la II República- había generado una profunda desmoralización, promoviendo la «inmoralidad», la "chabacanería» y lo "grosero». Ahora era necesario realizar un gran esfuerzo para desarraigar toda esa "mala hierba». Lo llamativo es que esa visión negativa no varió a lo largo del tiempo, manteniéndose durante las décadas de 1950 y 1960. A pesar de todos los esfuerzos realizados, los misioneros seguían considerando que vivían en una sociedad "profundamente inmoral» en la que los vestidos nunca eran lo suficientemente "discretos» y las diversiones jamás eran lo suficientemente "sanas". ${ }^{31}$ En 1959 los Asesores Eclesiásticos de Sindicatos de cada provincia fueron invitados a responder un cuestionario sobre la situación moral de su territorio, siendo las respuestas marcadamente pesimistas. El Asesor de Asturias dibujaba un panorama dantesco: se blasfemaba a todas horas, se ignoraba el precepto del descanso dominical y proliferaban las "situaciones escandalosas en playas, espectáculos y cines»..$^{32}$

Pero tras la Guerra Civil los misioneros tenían claro que el problema moral que había que afrontar con más urgencia era el de los denominados "amancebamientos», es decir, las parejas que convivían bajo un mismo techo sin estar casadas por la Iglesia. Los misioneros intentaron acabar con este tipo de uniones, proponiéndose que el matrimonio católico se convirtiese en la fórmula universal de institucionalización de la vida familiar. Para ello era fundamental poder disponer de un "censo" de los amancebados existentes en la localidad que iba a ser misionada, el cual era elaborado por el párroco. Una vez iniciada la misión, había que tratar por todos los medios que los concernidos aceptasen dejar de vivir «en pecado» y recibir el sacramento del matrimonio.

En las misiones celebradas durante la década de 1940 vamos a asistir a una verdadera avalancha de matrimonios de amancebados. Resulta evidente que durante estos años los misioneros estaban corrigiendo «situaciones irregulares» que se habían iniciado en los años de la II República, en un

30 Alfonsi 1999b: 365-385. José Andrés-Gallego y Antón M. Pazos precisan que la estrategia consistía en evangelizar primero e, inmediatamente, moralizar. En cualquier caso, el binomio recatolización-moralización resultaba evidente: Andrés-Gallego y Pazos 1999: 50.

31 Una visión que concordaba plenamente con la expresada por los obispos españoles en su "Instrucción sobre la moralidad pública» de 31 de mayo de 1957; véase: Iribarren 1974: 302-316. La insatisfacción del episcopado español con estado moral de la sociedad española constituyó un tema de aparición recurrente. Así, Antonio Martín Puerta pone de relieve cómo en 1939 el cardenal arzobispo de Toledo, Isidro Gomá, en su carta pastoral "Lecciones de la guerra y deberes de la paz» expresaba su preocupación por la inmoralidad reinante en la sociedad española y hacía votos para que el final de la guerra supusiese el inicio de un proceso de restauración moral. En 1955, el obispo de Solsona, Vicente Enrique Tarancón, alertaba de que los estándares morales no habían mejorado y que en algunos aspectos habían incluso empeorado; véase: Martín Puerta 2014: 150-175.

32 AGA, AES, 1959, Caja 21. contexto en el que las organizaciones políticas y sociales de la izquierda estaban fomentando una cultura laicista, anticlerical y desvalorizadora de las tradiciones fomentadas por la Iglesia. Estaba también la cuestión de los matrimonios civiles que se habían contraído al calor de la legislación republicana, considerados inválidos por la Iglesia y que los misioneros trataban de convertir en matrimonios católicos por todos los medios. Más reciente era aún la situación generada durante la Guerra Civil en aquellos territorios que habían permanecido en zona republicana: en ellos, la ausencia de clero y de estructuras eclesiásticas, unida a un clima violentamente antirreligioso, se tradujo en el inicio de convivencias de pareja no bendecidas por la Iglesia. Al mismo tiempo, debemos señalar que existían contingentes de población amancebada cuya situación no era achacable a un determinado clima laicista, sino a comportamientos sociales arraigados desde largo tiempo. Así, la costumbre de iniciar convivencias de pareja sin casarse - «llevarse a la novia»- parece haber estado bastante extendida entre grupos sociales en situación de marginación social - gitanos, chabolistas...-, entre los habitantes de ciertas zonas suburbiales urbanas o de determinadas localidades rurales particularmente pobres y alejadas de la influencia eclesiástica. ${ }^{33}$

En las misiones organizadas por la Asesoría Eclesiástica de Sindicatos durante la década de 1950 los matrimonios de amancebados continuaron constituyendo una práctica habitual, lo que demuestra que el problema estaba aún lejos de quedar resuelto. Durante la ya citada misión celebrada en la zona de canteras de Almería en 1950, además de bautizos de adultos, se llevaron a cabo matrimonios. ${ }^{34}$ En la campaña misional llevada a cabo en 1951 en la provincia de Albacete se celebraron también numerosas ceremonias matrimoniales. En Nava de Abajo, pedanía de Pozohondo, fueron 70 las parejas de amancebados a las que se pretendió casar, si bien la imposibilidad de reunir a tiempo la documentación necesaria hizo que la ceremonia no pudiese llevarse a cabo durante la misión. ${ }^{35} \mathrm{Y}$ en la misión celebrada en la cuenca minera de La Unión (Murcia) en 1961, donde - como vimos - habían sido abundantes los bautizos y las primeras comuniones de adultos, también fueron numerosos los matrimonios de amancebados. ${ }^{36}$

Sin embargo, la impresión dominante es que durante la década de 1960 los matrimonios fueron haciéndose cada vez más esporádicos en las misiones y, cuando se dieron, lo hicieron en ambientes sociales marcados por la marginación y la exclusión social. ${ }^{37}$ La explicación de ello sería que la incidencia de los amancebamientos habría descendido

33 Así, en 1941 Bernabé Copado decía lo siguiente a propósito de Montecorto, por entonces pedanía de Ronda (Málaga): «Aquí ven como la cosa más natural el que el novio se lleve a la novia; pero esto lo hacen de manera muy tranquila; el muchacho le dice a su madre y si no tiene confianza con su madre le dice a una parienta cualquiera: - Hoy me traigo a fulana - y se lleva a fulana; y ante el pueblo entero ya están constituidos en marido y mujer»; en: Copado 1973: 80 y ss.

34 Boletín de Información..., no 4, 1950.

35 Boletín de Información..., n요 10, 1952.

36 Boletín de Información..., no 49, 1962.

37 Así, durante la campaña misional celebrada en 1967 en Almería se van sucediendo algunos matrimonios de amancebados, todos ellos en barrios de pescadores muy pobres o en comunidades gitanas: AGA, AES, 1967, Caja 23-1. 
TABLA 3

Parejas de amancebados, matrimonios desunidos y tasa de ilegitimidad en tres comarcas misionadas por la Asesoría Eclesiástica de Sindicatos

\begin{tabular}{|c|c|c|c|c|c|}
\hline Campaña misional & Fecha & Población misionada & Parejas de amancebados & Matrimonios separados & Tasa de ilegitimidad (\%) \\
\hline Cuenca minera de Peñarroya-Pueblonuevo (Córdoba) & 1964 & 35.148 & 32 & 40 & 1,24 \\
\hline Valles de los ríos Alberche y Tiétar (Ávila) & 1965 & 15.838 & 18 & 23 & 1,66 \\
\hline Tierra de Campos (Zamora) & 1967 & 11.737 & 1 & 4 & 0,68 \\
\hline
\end{tabular}

Fuente: Elaboración propia a partir de documentación del AGA.

considerablemente respecto a las dos décadas anteriores, lo cual reflejaría un evidente éxito a la hora de promover el matrimonio católico como práctica casi universal, éxito al cual la actividad incesante de los misioneros no habría sido ajena. La Tabla 3 nos muestra el número de parejas de amancebados y de matrimonios desunidos contabilizados por la Asesoría Eclesiástica de Sindicatos en la cuenca minera de Peñarroya-Pueblonuevo, en los valles de los ríos Alberche y Tiétar y en la comarca de Tierra de Campos de cara las misiones que fueron llevadas a cabo en dichos territorios en 1964, 1965 y 1967, respectivamente. Nos muestra, además, la tasa de ilegitimidad para las tres zonas, siempre según los datos de la Asesoría.

Lo más llamativo de los datos es que, a pesar del diferente comportamiento religioso observado en las comarcas misionadas - la comarca cordobesa presentaba unos bajos índices de práctica religiosa, mientras que la abulense y la zamorana los presentaban altísimos-, los comportamientos matrimoniales parecen haber sido muy similares. El número de parejas de amancebados y de matrimonios separados era realmente bajo. La tasa de ilegitimidad era también muy baja. ${ }^{38}$ En las tres zonas se había llegado a una situación en la que el modelo católico de familia dominaba de una manera incontestada, sin que los menores índices de práctica religiosa de PeñarroyaPueblonuevo influyeran en ello.

Acabar con la práctica del amancebamiento era el principal objetivo moralizador de las misiones, pero no el único. La Asesoría poseía todo un programa de acción que incluía «la lucha contra la blasfemia, contra la infracción del descanso dominical y del precepto de oír la Santa Misa; contra los juegos prohibidos, contra la embriaguez, contra la pornografía y relajación de costumbres en cualquiera de sus manifestaciones y contra la usura». ${ }^{39}$ De una manera especial, erradicar la blasfemia y hacer cumplir el precepto del descanso dominical estuvieron entre sus objetivos prioritarios.

Por lo que respecta a la blasfemia, la Asesoría siguió dos vías para intentar acabar con ella. Por una parte organizó "campañas contra la blasfemia» que incluían la colocación de carteles, el reparto de octavillas o la emisión de cuñas radiofónicas, y que se dirigían a determinados grupos profesionales a los que se consideraba propensos

38 En 1965 los «ilegítimos y expósitos» suponían un 1,6\% del total de nacidos vivos en España. La tasa de ilegitimidad venía experimentando un descenso sostenido desde mediados de la década de 1950, cuando se había situado en valores en torno al 4,5\%; véase: Vázquez 1967: 169.

39 Boletín de Información..., no 1, 1950. a blasfemar, como los mineros o los pescadores. ${ }^{40}$ Estas campañas eran reforzadas por las misiones, en las cuales se hacía hincapié en la idea de que la blasfemia conducía a la condenación eterna. ${ }^{41}$ La otra vía de actuación consistió en presionar a las autoridades civiles para que sancionasen a los blasfemos. El Código Penal de 1944 había reintroducido el "delito de blasfemia», por lo que existía una base legal para actuar; pero la Asesoría consideraba que las autoridades no estaban siendo rigurosas a la hora de aplicar la ley. Los Asesores Provinciales contactaban frecuentemente con los Gobernadores Civiles y los Alcaldes, solicitándoles que quienes fuesen descubiertos blasfemando fuesen multados y la Asesoría Nacional llegó a proponer que se multase a aquellas empresas que no sancionasen disciplinariamente a aquellos de sus empleados que blasfemasen durante las horas de trabajo. ${ }^{42}$ En 1954 la Asesoría se mostraba convencida de que estos esfuerzos estaban dando fruto: según una encuesta realizada por ella misma, la práctica de la blasfemia estaba disminuyendo entre los trabajadores españoles. ${ }^{43}$

Por su parte, la lucha contra el trabajo en domingo poseía un importante valor simbólico. El domingo, día del Señor, debía ser santificado. Continuar con las actividades laborales durante dicho día - siempre y cuando no existiesen motivos de fuerza mayor que lo justificasenrevelaba una débil formación religiosa y, en algunos casos, podía constituir una forma encubierta de mostrar actitudes irreligiosas. Debido a ello, antes de iniciar una misión en una determinada localidad, los misioneros eran informados por los párrocos de si la práctica de trabajar en domingo estaba extendida en la misma, a fin de que abordasen la cuestión durante sus predicaciones.

Pero al igual que ocurrió con la cruzada contra la blasfemia, la Asesoría Eclesiástica de Sindicatos decidió complementar la labor misional con presiones a las autoridades civiles. Los Asesores se quejaban de que la Ley de Descanso Dominical de 1940 era incumplida con frecuencia. En 1952 la I Asamblea Social Sacerdotal celebrada en León, a la cual

$40 \quad$ En 1947 la Asesoría Eclesiástica de Pontevedra puso en marcha una campaña dirigida a los pescadores. En ella se incluyó un «concurso de dibujo infantil», en el cual los escolares debían aportar diseños que desalentasen a sus padres de blasfemar: AGA, AES, 1947, Caja 25.

41 Así, la lucha contra la blasfemia fue un elemento destacado de las misiones llevadas a cabo en las cuencas mineras de Palencia y León en 1958 y 1959, dado que se la consideraba un pecado fuertemente arraigado entre los mineros de dichas provincias: AGA, AES, 1958 y 1959, Cajas $24-3$ y $23-3$.

42 Boletín de Información..., no 13, 1953.

43 Boletín de Información..., no extraordinario, 1954. 
acudieron representantes de la Asesoría, llegó a proponer que se atribuyese a las autoridades eclesiásticas capacidades ejecutivas a la hora de hacer cumplir dicha ley. ${ }^{44}$ Una cuestión con la que los Asesores estaban especialmente sensibilizados era la de los mercados dominicales que se celebraban en las plazas mayores de numerosos pueblos. Debido a ello, dirigieron numerosas peticiones a los Gobiernos Civiles y a las Alcaldías para que pusiesen fin a los mismos. Así, en 1959 el Asesor de Guipúzcoa se jactaba de que gracias a sus gestiones el mercado de Rentería había sido trasladado al sábado. ${ }^{45}$ En ocasiones, este tipo de actuaciones podían dar lugar a conflictos con la población afectada. Es lo que ocurrió en 1954, cuando las gestiones del Obispo de Astorga se saldaron con la supresión del mercado dominical de Puebla de Sanabria (Zamora), lo cual originó un fuerte descontento en toda la comarca, debido a la importancia económica que el mismo poseía. Este hecho, unido a que el Obispo hubiese dado instrucciones a los párrocos para que no oficiasen misas en aquellas fiestas populares en que se celebrasen bailes, había generado un alud de críticas a la autoridad eclesiástica. ${ }^{46}$

Precisamente los bailes constituyeron otro de los caballos de batalla de los misioneros de la Asesoría. Los bailes los que se celebraban con ocasión de fiestas populares y, sobre todo, los que se llevaban a cabo en locales de ocio específicamente habilitados para ello- se convirtieron en el símbolo por antonomasia de la inmoralidad. Bailar fomentaba el contacto desenfadado entre jóvenes de ambos sexos, lo cual suponía exponerlos a pensamientos pecaminosos que, a menudo, se traducían en relaciones prematrimoniales, con su corolario inevitable de pérdida de pureza y apartamiento de la senda de la virtud. ${ }^{47}$

Como el resto de preocupaciones morales de los eclesiásticos, la polémica contra el baile fue incorporada por los misioneros, quienes pusieron todo de su parte por anatemizar esta práctica y convencer a la juventud de su inconveniencia. Se trataba, sin embargo, de una labor difícil. En la inmensa mayoría de los pueblos españoles la celebración de las fiestas conllevaba la organización de un baile que era aguardado con impaciencia por parte de los jóvenes. Como consecuencia de ello, los misioneros tuvieron que ver cómo, a menudo, sus admoniciones eran desoídas de manera deliberada. ${ }^{48}$

La Asesoría Eclesiástica de Sindicatos centró sus esfuerzos en la lucha contra las salas de bailes, consideradas como locales perniciosos cuyo negocio consistía en uperder a la juventud». Ante todo, los misioneros de la Asesoría esperaban que dichas salas permaneciesen cerradas durante los días que durase la misión y para lograrlo no dudaban

44 Boletín de Información..., no 13, 1953.
45 AGA, AES, 1959, Caja 21.
46 AGA, AES, 1954, Caja 28.
47 Véase: Regueillet 2004: 1027-1042. También: Ferrer Senabre 2012: 1-9.

48 Bernabé Copado nos relata cómo, durante la década de 1940, en diferentes pueblos andaluces se llegaron a celebrar bailes incluso durante los días de misión. En Zamoranos, aldea perteneciente al municipio de Priego de Córdoba, los misioneros jesuitas predicaban todos los años una novena, siendo costumbre que el último día una hermandad local contratase una orquesta y se celebrase un baile. En 1947 la hermandad, requerida por los misioneros, decidió no traer la orquesta. La población, enfadada, reaccionó no acudiendo al acto final de la novena: Copado 1973: 311-317. en recurrir a presiones tanto sobre sus propietarios como sobre los alcaldes. Habitualmente, los misioneros solían lograr este objetivo. Cuando no lo lograban se sentían escandalizados. En 1965, en Casillas (Ávila) se sucedieron tres días seguidos de baile, a pesar de que se estaba llevando a cabo una misión. El misionero se mostró molesto debido a que el alcalde no había hecho nada para impedirlo. ${ }^{49}$

Lo ideal era que el cierre de las salas de baile durante los días de misión se convirtiese en un primer paso hacia su clausura definitiva. De este modo, la misión habría actuado como un hito en la moralización de la vida pública de la localidad misionada. Para lograr este objetivo, los misioneros incitaban a los párrocos a iniciar gestiones cerca de los propietarios de las salas de baile y de las autoridades locales. Se trataba de un objetivo difícil, dado que chocaba con los intereses empresariales de los propietarios y con la demanda de bailes por parte de los jóvenes; pero en algunas ocasiones se consiguió materializarlo. Así, en 1959 la Asesoría felicitaba al párroco de Candanedo de Fenar, localidad encuadrada en el municipio de La Robla (León), porque había logrado que cerrase el salón de baile. Se remarcaba que el éxito se había conseguido "sin prohibiciones», simplemente convenciendo al propietario de que era mejor dedicar el local a otros fines comerciales "en nada reñidos con la moral». ${ }^{50}$

La preocupación de los misioneros por la influencia de las salas de baile y otras formas de ocio sobre el comportamiento moral de la población les llevó a elaborar censos de los locales dedicados a la diversión que se mantenían abiertos en las zonas que iban a ser misionadas. Ello les permitía identificar en qué localidades resultaba más acuciante el peligro de las diversiones inmorales. En la Tabla 4 presento la incidencia de estos "locales de diversión» — salas de baile y cines - en cinco zonas geográficas distintas, misionadas por la Asesoría. Asimismo, relaciono dicha incidencia con las actitudes religiosas dominantes en tales zonas.

Los datos no sustentan la idea de que una mayor incidencia de los locales de diversión afectase a la vida religiosa. En las cuencas mineras de Palencia y León la diferente incidencia de las salas de baile y cines sensiblemente superior en el caso leonés- no se traducía en índices de práctica religiosa distintos. Por su parte, en Puertollano y en Peñarroya-Pueblonuevo, donde la disponibilidad de salas de baile y cines era inferior, los niveles de práctica religiosa eran los más bajos. Finalmente, en Tierra de Campos, donde encontramos en 1967 la mayor accesibilidad a locales de diversión, los niveles de práctica religiosa eran prácticamente unánimes. Es cierto que los misioneros no vinculaban las diversiones «insanas» a la irreligiosidad, sino a los comportamientos inmorales. Lamentablemente, no es posible reconstruir el número de amancebamientos y la tasa de ilegitimidad de las cuencas mineras de Palencia y León y de Puertollano. Pero los datos que sí poseemos para la cuenca minera de PeñarroyaPueblonuevo y para Tierra de Campos, y que expusimos en la Tabla 3, desmienten también la relación entre salas de diversión e inmoralidad.

\footnotetext{
49 AGA, AES, 1965, Caja 23-1.

50 AGA, AES, 1959, Caja 23-3.
} 
TABLA 4

Locales de diversión (salas de baile y cines) y actitudes religiosas en cinco zonas geográficas misionadas por la Asesoría Eclesiástica de Sindicatos

\begin{tabular}{|c|c|c|c|c|c|c|}
\hline Campaña misional & Fecha & $\begin{array}{l}\text { Población } \\
\text { misionada }\end{array}$ & $\begin{array}{l}\text { Locales de } \\
\text { diversión }\end{array}$ & $\begin{array}{l}\text { Habitantes / local } \\
\text { de diversión }\end{array}$ & $\begin{array}{l}\text { Cump. dominical } \\
\text { (\%) }\end{array}$ & Cump. Pascual (\%) \\
\hline Cuenca minera de Palencia & 1958 & 29.509 & 21 & $1.405,2$ & 81,3 & 91,4 \\
\hline Cuenca minera de León & 1959 & 56.506 & 62 & 911,3 & 77,3 & 90,1 \\
\hline Puertollano (Ciudad Real) & 1961 & 53.136 & 8 & $6.642,0$ & 20,2 & 26,1 \\
\hline $\begin{array}{l}\text { Cuenca minera de Peñarroya-Pueblonuevo } \\
\text { (Córdoba) }\end{array}$ & 1964 & 35.148 & 13 & $2.703,7$ & 37,5 & 44,5 \\
\hline Tierra de Campos (Zamora) & 1967 & 11.737 & 25 & 469,5 & 90,2 & 93,7 \\
\hline
\end{tabular}

Fuente: Elaboración propia a partir de documentación del AGA. ${ }^{51}$

CAMBIO SOCIAL Y MISIONES: LOS MISIONEROS ANTE LAS TRANSFORMACIONES SOCIALES DE LA DÉCADA DE 1960

Ya desde finales de la década de 1950, pero sobre todo durante la década de 1960, los misioneros van a tomar conciencia de que la sociedad española estaba experimentando una serie de cambios económicos y sociales que tendían a obstaculizar y dificultar su labor moralizadora. La intensificación de los movimientos migratorios; el «boom» turístico; o la incipiente conformación de una sociedad de consumo van a generar un proceso de cambio social que se va a traducir en la conformación de una nueva cultura..$^{52}$ En líneas generales, los misioneros de la Asesoría Eclesiástica de Sindicatos van a expresar una visión muy negativa de ese proceso, en el que van a ver la semilla del futuro fracaso de todos los esfuerzos de recatolización que habían venido desarrollando desde el final de la Guerra Civil.

Los misioneros vinculados a la Asesoría veían con inquietud los movimientos migratorios. La emigración suponía, por una parte, el que habitantes de determinadas zonas rurales donde la tradición católica estaba fuertemente asentada se trasladasen a vivir a zonas urbanas donde los niveles de práctica religiosa eran más bajos y donde existía el peligro de que, deslumbrados por la vida de ciudad, terminasen por abandonar las costumbres adquiridas en sus lugares de origen. Pero, al mismo tiempo, la emigración estaba llevando a determinadas regiones tradicionalmente caracterizadas por una alta religiosidad a población que procedía de otras regiones menos religiosas, existiendo el peligro de que con la llegada de estos inmigrantes llegasen también los «malos ejemplos» y que éstos terminasen por influir sobre la población local. ${ }^{53}$

51 Municipios misionados en Palencia: Barruelo de Santullán; Brañosera; Castrejón de la Peña; Cervera de Pisuerga; Guardo; Mantinos; Mudá; La Pernía; San Cebrián de Mudá; Santibáñez de la Peña; Velilla del Río. Municipios misionados en León: Boñar; Cármenes; Carrocera; Cistierna; Cuadros; La Ercina; Garrafe de Torío; Matallana de Torío; La Pola de Gordón; Rioseco de Tapia; La Robla; Rodiezmo; Sabero; Santa María de Ordás; Santovenia de la Valdoncina; Vegaquemada. Municipios misionados en Ciudad Real: Puertollano.

52 Bernecker 2009: 49-70.

53 Uno de los ponentes del Segundo Congreso de Misiones lo expresó de manera elocuente: "Los movimientos de población hacen fluctuar de manera muy sensible los niveles de religiosidad de los pueblos. En zonas de fuerte inmigración la piedad sufre con frecuencia vertiginosos descensos, por aquello de que allí, por lo general, confluye lo
Ambas situaciones confluyeron en las cuencas mineras de Palencia y León donde, como sabemos, la Asesoría llevó a cabo misiones en 1958 y 1959, respectivamente. Como podemos comprobar en la Tabla 4, ambas cuencas mantenían unos niveles de práctica religiosa altos. Sin embargo, tanto los párrocos de las localidades misionadas como los propios misioneros temían que los movimientos migratorios terminasen por erosionar tal situación en un futuro. Por una parte, ambas zonas estaban recibiendo a inmigrantes procedentes de Galicia, Extremadura y Andalucía. Éstos eran conceptuados como "menos religiosos» y "peor formados» que la población autóctona, existiendo el peligro de que terminasen por "contagiar» a esta última. En 1959 el misionero dominico que visitó Sabero, en León, confirmaba el diferente comportamiento religioso de los «nativos» y los que él denominaba «advenedizos», es decir, los inmigrantes. De estos últimos decía:

Los advenedizos - gentes venidas de diversas regiones en busca de trabajo-, se mantienen en general, en un nivel religioso inferior. Quizá la falta de formación y el sentirse sin compromisos sociales y verse en tierra extraña donde lazos atávicos no les empujan a cumplir con sus obligaciones religiosas, explican este fenómeno. Junto, claro está, con el materialismo de su vida. ${ }^{54}$

Pero al mismo tiempo que recibían a inmigrantes procedentes de otras regiones, las cuencas mineras de Palencia y León también estaban enviando emigrantes al exterior, particularmente a la ciudad de Bilbao. Este movimiento emigratorio era visto también con inquietud. Los párrocos advertían que muchos de los que emigraban, cuando regresaban a visitar a sus familiares, demostraban no haber seguido una "vida de parroquia» en Bilbao. El párroco de Santibáñez de la Peña (Palencia) afirmaba en 1958 que los que habían emigrado, cuando regresaban a pasar unos días en su localidad de origen, fomentaban el «materialismo» e incitaban a otros a emigrar. ${ }^{55}$ La emigración

peor de cada casa. Los emigrados tardan en integrarse o no se integran nunca en sus nuevas parroquias y no con rara frecuencia desintegran a los nativos»: Congreso 1961: 192. Por lo demás, las repercusiones negativas de las migraciones sobre la religiosidad fueron intensamente tratadas por la sociología católica de la época: Vázquez 1965: 156-180.

54 AGA, AES, 1959, Caja 23-3.

55 AGA, AES, 1958, Caja 24-3. 
era vista como una vía a través de la cual los habitantes de zonas como Palencia o León, donde el impacto del proceso de secularización había sido muy bajo y donde los niveles de práctica religiosa se mantenían altos, podían perder ese tesoro trabajosamente defendido durante siglos.

En 1961, el Asesor Eclesiástico de Sindicatos de la provincia de León creyó haber encontrado la solución al problema religioso de los emigrantes. Se trataba de que los párrocos de sus localidades de origen llevasen un fichero en el que se hiciese constar «el origen de la familia que emigra, sus antecedentes históricos, económicos, causas que le han determinado a emigrar, aptitud profesional, su nivel cultural, grado de catolicismo, puntos flacos que tienen, sus aspiraciones». A través de los datos contenidos en este fichero, se contactaría con la diócesis de destino, la cual a su vez informaría al párroco de la zona donde se instalase el emigrante. Aquél se encargaría de visitar al inmigrante recién llegado y de velar porque su traslado de domicilio no fuese acompañado por el abandono de su anterior vida religiosa. ${ }^{56} \mathrm{El}$ que se llegase a pensar en este procedimiento - de imposible cumplimiento, dado que implicaba perseguir a los emigrantes por todo el territorio nacional- revela el grado de confusión que el cambio social estaba provocando en la Asesoría. Finalizada la Guerra Civil, los misioneros habían comenzado a actuar sobre una determinada realidad religiosa históricamente configurada. Se partía del hecho de que las zonas rurales presentaban niveles de religiosidad más altos que las zonas urbanas y de que regiones como Castilla, País Vasco o Navarra presentaban índices de práctica religiosa más elevados que otras como Extremadura o Andalucía. Y se aspiraba a homogeneizar los índices de práctica religiosa a través de instrumentos como las misiones. Ahora las migraciones interiores, en la medida que implicaban el traslado de personas desde ámbitos de alta tradición religiosa a ámbitos de baja tradición, y viceversa, amenazaban con trastocar todo lo que se conocía sobre la religiosidad de los españoles y con configurar un mapa absolutamente nuevo, ante el cual no se sabía cómo actuar.

El «boom» experimentado por el turismo durante la década de 1960 constituyó otro motivo de alarma. La entrada de turistas extranjeros constituía una fuente de preocupación moral, dado que con ellos llegaban los «malos ejemplos». Los turistas introducían una visión desprejuiciada de las relaciones sexuales que amenazaba con ser asumida como propia por la sociedad española. ${ }^{57}$ Al mismo tiempo, las actividades turísticas tenían efectos destructivos sobre la cultura de las comunidades locales, tendiendo a mercantilizar las relaciones sociales $y$, como consecuencia de ello, a difundir una «mentalidad materialista» que terminaba siendo difícilmente conciliable con la vida religiosa. El propio turismo de interior llevado a cabo por españoles, era contemplado como algo no del todo inocuo. Quienes abandonaban sus ciudades de residencia para pasar unos días de asueto en la playa o en la montaña tendían a adoptar comportamientos relajados que, a menudo, se apartaban de los códigos morales que seguían en su vida cotidiana, ejerciendo de este modo

\footnotetext{
56 Boletín de Información..., no 47, 1961.

57 Véase: Pack 2009: 131 y ss.
}

una influencia nociva sobre las localidades en las que veraneaban. $^{58}$

El auge que estaba adquiriendo la actividad turística en Capdepera (Mallorca) fue el motivo que llevó a la Asesoría a organizar una misión en ella en 1964. Su párroco la presentó a los misioneros como una localidad marcada por la inmoralidad. Pese a contar con sólo con unos 3.000 habitantes, se contabilizaban 15 amancebamientos y 20 matrimonios desunidos, calculándose una tasa de ilegitimidad del 3,2\%. Existían varios salones de baile «de dudosa nota» y los menores acudían al cine "sin control alguno». Los índices de cumplimiento dominical y pascual eran cifrados en apenas un $60 \%$. El párroco atribuía este ambiente de inmoralidad al influjo del turismo. ${ }^{59}$

Las repercusiones nocivas que la Asesoría atribuía al turismo nacional quedan ilustradas a través de la campaña misional organizada en 1965 en los valles del Alberche y del Tiétar, en la provincia de Ávila. Durante los meses estivales algunos de los pueblos de estas comarcas duplicaban su población por la llegada de veraneantes. El informe socio-religioso elaborado con vistas a la realización de las misiones señalaba que su presencia ejercía una influencia negativa. Ciertamente la situación moral de estas comarcas abulenses distaba mucho de ser "escandalosa», como se constata a través de la Tabla 3: con más de 15.000 habitantes, poseían un número de parejas de amancebados y de matrimonios desunidos similar al que Capdepera poseía con una población bastante inferior. No obstante, tanto los párrocos como los misioneros constataban con desazón que algo estaba cambiando en la vida moral de aquellos pueblos abulenses. En concreto, inquietaba el que los amancebamientos no causasen un "rechazo social» por parte del vecindario tan intenso como el que habían causado en el pasado. Se echaba en falta una "reacción colectiva» ante tal tipo de situaciones. ${ }^{60} \mathrm{Al}$ mismo tiempo, se constataba que la vida sexual de sus habitantes estaba cambiando. Casi todos los párrocos aseguraban que desde hacía algunos años se observaba un recurso muy extendido al control de la natalidad, lo cual se había traducido en una reducción del número de nacimientos. El párroco de Casillas aseguraba que el hecho de que durante los últimos cinco años no hubiese nacido ningún hijo ilegítimo no era achacable a que no existiesen relaciones fuera del matrimonio, sino a que quienes las mantenían recurrían a métodos anticonceptivos. ${ }^{61}$

58 Así, el jesuita José Sola no dudaba en afirmar en el Segundo Congreso de Misiones: "Son los hombres y mujeres de ciudad los introductores y los exportadores al campo de las malicias, vicios, vestidos, irreligiosidad e impiedad, que actúa en los pueblos precisamente por la fascinación que ejerce sobre ellos la ciudad, con enorme corrosividad. Cambian las costumbres y disuelven siglos de tradiciones y de ideas en unas vacaciones»: Congreso 1961: 219-220.

59 AGA, AES, 1964, Caja 23-3.

60 AGA, AES, 1965, Caja 24-1.

61 La existencia de un fuerte interés por los anticonceptivos anovulatorios (la "píldora») es constatable en la sociedad española desde inicios de la década de 1960 y se vería reforzado a partir del inicio de su comercialización legal, en 1964. La posición de la jerarquía católica había sido siempre contraria a la contracepción. Sin embargo, el clima de cambio generado por el Concilio Vaticano II y la aparición en escena de médicos y teólogos católicos que propugnaban alguna forma de acomodamiento entre las nuevas técnicas anticonceptivas y la moral católica generaron dudas que no serían despejadas hasta la publicación 
Tanto los misioneros como los párrocos tenían la sensación de estar asistiendo a un proceso de cambio en el modo de vivir la sexualidad por parte de la sociedad española para afrontar el cual no estaban preparados. Ambos habían hecho suyo el mensaje tradicional de la Iglesia en el sentido de que la sexualidad era lícita únicamente cuando se desarrollaba en el seno del matrimonio y con fines reproductivos. Ahora debían constatar cómo, incluso en comunidades donde la asistencia a misa continuaba siendo alta, las prácticas sexuales de la población se apartaban cada vez más de estos estándares morales. Así, con motivo de una misión celebrada en Pamplona en 1964, no organizada directamente por la Asesoría, pero en la cual ésta colaboró activamente, se distribuyó entre los misioneros unas "orientaciones para los confesores» en las cuales se hacía hincapié en la necesidad de censurar cualquier práctica que fuese destinada a controlar la natalidad en el seno del matrimonio. No obstante, se reconocía que el control de la natalidad estaba muy extendido en la sociedad pamplonesa y que incluso se hablaba del mismo en "tertulias de señoras». ${ }^{62}$

El crecimiento económico experimentado durante la década de 1960 puso las bases de la sociedad de consumo en España. El incremento del nivel de renta de la población se tradujo en una intensificación de la adquisición de bienes de consumo, fenómeno éste que fue acompañado de una creciente influencia de los procesos de conformación de identidades culturales ligadas al consumo. ${ }^{63}$ Los misioneros de la Asesoría contemplaban con gran inquietud este fenómeno, detrás del cual veían una oleada de "materialismo» que resultaba difícilmente compatible con los modos de vida religiosos tradicionales. ${ }^{64}$ Entre las novedades introducidas por la sociedad de consumo, una de las que mayor preocupación causaba era la televisión, a la que se acusaba de constituir un altavoz del nuevo espíritu materialista, pero también de «robar» asistencia a la iglesia.

por Pablo VI de la encíclica «Humanae vitae» en 1968; véase: Rodríguez Ocaña, Ignaciuk y Ortiz Gómez 2012: 467-494. Claramente, la Asesoría se alineó siempre con la interpretación tradicionalista, posición ésta que plasmó en la organización de unos «cursillos de regulación de la natalidad» en los cuales se explicaba la ilicitud de la «píldora» y se proponía como alternativa el método Ogino-Knaus. En 1970 afirmaba haber llevado a cabo 44 de estos cursillos, con una asistencia de 7.879 personas: AGA, AES, 1971, Caja 10.

62 AGA, AES, 1964, Caja 23-3.

${ }^{63}$ La sociología constata que, sin llegar a ser plenamente una sociedad de consumo de masas, España avanzó en tal sentido a lo largo de la década de 1960, especialmente durante el tramo final de la misma. La proporción de hogares que poseían un automóvil pasó del 4\% en 1960 al $27 \%$ en 1970; los que poseían un frigorífico, pasaron del $4 \%$ al $63 \%$; y los que poseían un receptor de televisión, del $1 \%$ al $62 \%$; véase: De Miguel 1998: 107-149.

64 Este malestar con la cultura moderna no era privativo de los sectores tradicionalistas de la Iglesia, sino que era constatable también en algunos de los representantes del sector más aperturista. Así, en 1968 Ramón Echarren Istúriz, quien habría de actuar como mano derecha del cardenal Tarancón durante la década de 1970, alertaba de que las transformaciones socio-económicas de la España de la década de 1960 habían traído consigo algunos efectos «indeseados», tales como la «insatisfacción y la frustración permanentes»; la «infantilización de los comportamientos»; la "alienación y la despersonalización en el trabajo»; todo lo cual había dado lugar a un hombre «dislocado, empobrecido o mal equipado en el plano de lo afectivo y lo espiritual»; véase: Echarren Istúriz 1968: 73-110.
En 1965 se aseguraba que en Cardeñosa (Ávila) había chicas jóvenes que habían abandonado la catequesis «por culpa de la televisión». ${ }^{65}$ Y ese mismo año un acto misional celebrado en Boltaña (Huesca) quedó casi desierto porque la población estaba pendiente de un partido internacional entre el Real Madrid y el Benfica que era retransmitido por televisión. ${ }^{66}$

La preocupación por el impacto de la televisión llevó a la Asesoría a elaborar estimaciones sobre el número de receptores existentes en las comarcas donde se iban a llevar a cabo misiones. Este dato servía para orientar a los misioneros sobre el grado de penetración que la nueva cultura consumista había alcanzado en las localidades que iban a visitar, lo cual les ayudaría a tomar decisiones sobre los temas a abordar en sus predicaciones. De este modo, siempre en base a las estimaciones de la Asesoría, en la cuenca minera de Peñarroya-Pueblonuevo, en 1964, existían sólo 6,8 televisores por cada 1.000 habitantes. ${ }^{67}$ En los valles del Alberche y el Tiétar, en 1965, el número era sensiblemente superior: $17,2 .^{68} \mathrm{Y}$ en Tierra de Campos, en 1967, la cifra era de $23,3 .{ }^{69}$ Como podemos ver, los datos no confirman los supuestos efectos disruptivos de la televisión sobre la práctica religiosa y la moralidad. PeñarroyaPueblonuevo, donde la población estaba menos influida por la televisión, presentaba los niveles de práctica religiosa más bajos, mientras que los valles del Alberche y del Tiétar y Tierra de Campos, pese a presentar una penetración del medio televisivo superior, habían conservado unos niveles propios de comunidades tradicionales escasamente secularizadas.

Los misioneros de la Asesoría realizaron una valoración pesimista de los cambios culturales que se estaban produciendo en la década de 1960 no tanto por las consecuencias que estuvieran produciendo en aquellos momentos como por las potenciales que podían acarrear en un futuro. En realidad, resultaba difícil defender que los cambios experimentados por la sociedad española se estuviesen traduciendo en un abandono de la práctica religiosa. ${ }^{70}$ Las zonas que, como Ávila o Zamora, habían presentado tradicionalmente altos índices de práctica religiosa los seguían manteniendo. En las zonas donde los índices eran bajos, como Córdoba, los mismos obedecían a dinámicas largamente asentadas en el tiempo, pero no, desde luego, al impacto de la nueva cultura, la cual, además, parece haber presentado una influencia menor en ellas. Por lo demás, los amancebamientos y los nacimientos ilegítimos presentaban una incidencia muy baja, tanto en zonas de alta práctica religiosa como en zonas de menor cumplimiento. Ningún indicador mostraba que España estuviese en

65 AGA, AES, 1965, Caja 24-1.

66 AGA, AES, 1965, Caja 23-2.

67 AGA, AES, 1964, Caja 24-1.

68 AGA, AES, 1965, Caja 24-1.

69 AGA, AES, 1967, Caja 23-3.

70 Es cierto que la geografía de las misiones de la Asesoría condicionaba sus resultados. La Asesoría concentraba su trabajo en localidades agrarias y mineras de tamaño mediano y pequeño y nunca misionaba en grandes núcleos urbanos, donde el impacto de los cambios culturales de la década de 1960 era más intenso. En este sentido, una comparación entre los resultados de las misiones de la Asesoría y los de otras celebradas en grandes ciudades por iniciativa de otros institutos religiosos resultaría de gran interés. Para una explicación de la geografía de las misiones de la Asesoría, véase: Bernal García 2015: 231-236. 
vísperas de experimentar una oleada secularizadora pero, a pesar de ello, los misioneros de la Asesoría presagiaron que en los cambios socioculturales que se estaban produciendo estaba el germen de un nuevo período de dificultades para la Iglesia. Como sabemos, esta intuición resultó ser acertada. ${ }^{71}$

Junto con los cambios económicos, sociales y culturales, la Asesoría Eclesiástica de Sindicatos también tuvo que hacer frente durante la década de 1960 a cambios estrictamente religiosos. El Concilio Vaticano II (1962-1965) propició una renovación de la Iglesia y de los métodos de comunicación religiosa que, en muchos sentidos, chocó con la impronta fuertemente tradicionalista que la Asesoría imprimía a sus actividades. $^{72}$

Como ha señalado Claude Prudhomme, a partir del Concilio la palabra «misión» se utilizó cada vez menos en los documentos pontificios, siendo preferido a la misma el término de "evangelización». Para la nueva sensibilidad católica, la «misión» estaba asociada a la mentalidad del "catolicismo de reconquista» y a la idea de una Iglesia "triunfalista y autoritaria». Mientras que «evangelización» significaba dar testimonio de la fe de una manera «simple, directa y a través del compromiso social» y evocaba la idea de una Iglesia «humilde y pobre ${ }^{73}$ No sorpresivamente, durante la década de 1960 las misiones interiores entraron en crisis en la Europa católica, constituyendo el caso de España una excepción, en la medida en que instituciones como la Asesoría Eclesiástica de Sindicatos se esforzaron por mantenerlas. La Asesoría no se adaptó a los nuevos vientos que soplaban desde Roma y su esfuerzo por mantener íntegro el modelo tradicional de misión, basado en actos espectaculares y triunfalistas; centrado en el mensaje de pecado, redención y miedo ante la proximidad de la muerte; y huérfano, en gran medida, de contenidos sociales, así lo atestigua. ${ }^{74}$

A pesar de ello, se produjeron situaciones en las que la influencia del nuevo clima religioso creado a partir del Concilio se dejó sentir en la actuación de algunos de los misioneros que colaboraban con la Asesoría, particularmente entre los más jóvenes. Así, vamos a encontrar misioneros que, con sus opiniones o sus prácticas, van a cuestionar la línea tradicionalista de la Asesoría. Lo constatamos en los informes que dirigían a la Asesoría una vez finalizadas sus predicaciones, en los cuales encontramos en ocasiones críticas al modelo tradicional, mostrándose partidarios de introducir cambios en el mismo. Así, en 1960 el responsable de una misión llevada a cabo en El Astillero, en la provincia de Santander, después de remarcar que la misma se había

71 En este sentido, resultan interesantes las aportaciones de diferentes sociólogos que presentan la secularización de la sociedad española como un fenómeno que se habría producido, fundamentalmente, desde mediados de la década de 1970 en adelante; véase: Requena 2008: 319-343.

72 Feliciano Montero describe esta transformación señalando que a comienzos de la década de 1960 se produce «un cambio radical de valores y actitudes: reconocimiento de los problemas reales, descubrimiento de valores evangélicos desde abajo, diálogo y reconocimiento tolerante de otras militancias y compromisos fuera de las organizaciones católicas, con las que se estaba dispuesto a colaborar»; véase: Montero 2009: 123-124.

73 Prudhomme 2000: 119-132.

74 Para todo lo referente a los contenidos de las misiones de la Asesoría, así como a las técnicas de comunicación empleadas, me remito a: Bernal García 2015: 227-253. desarrollado de conformidad con el «método tradicional» y de reconocer que su resultado no había sido exitoso, realizó el siguiente apunte crítico:

¿No sería conveniente revisar los programas? Nos quejamos todos de que el esquema misional está totalmente anticuado, que estamos dando una misión como hace varios siglos, cuando los tiempos han cambiado tanto. A la hora de la verdad quedamos pasmados porque no hay tema para la gracia, ni para Jesucristo, ni para los Sacramentos como vida divina. Los temas principales de la espiritualidad quedan fuera de este plan misional. ${ }^{75}$

A comienzos de la década de 1970 vamos a encontrar algunos misioneros que, ignorando las directrices de la Asesoría, van a desarrollar su propio programa de actos, imprimiendo a los mismos un carácter renovado. Así, en la campaña desarrollada en la provincia de Zamora en el año de 1970 observamos que el método tradicional convive con un intento de renovar el programa de actos. En la mayoría de los pueblos la misión sigue el esquema tradicional: rosario de la aurora, vía crucis, misión infantil y acto general, el cual se salda, en la mayoría de los casos, con comuniones unánimes. Pero en algunos pueblos los misioneros se apartan del mismo y enfocan su actividad desde un prisma nuevo. Así, en el municipio de Villar del Buey la misión fue organizada como un conjunto de charlas parroquiales en las que eran los propios fieles los que proponían los temas que deseaban que fuesen tratados. En concreto, un grupo de jóvenes planteó que se abordase el tema de la sexualidad, "enfocándolo el misionero por la vía de su indisoluble unión a la vida marital». ${ }^{76}$ Así mismo, en la campaña realizada en 1972 en la provincia de Jaén volvemos a encontrar esta dicotomía entre misioneros que siguen el esquema tradicional y misioneros que desarrollan fórmulas innovadoras. Así, en Alcaudete la misión siguió estrictamente los protocolos tradicionales, con la celebración del rosario de la aurora, el vía crucis y el acto general, y con los misioneros dedicando buena parte de su tiempo a solucionar "casos difíciles y escandalosos", es decir, a lograr que los amancebados se casasen por la Iglesia. Por el contrario, el misionero de Garcíez dio una dimensión totalmente distinta a su actuación, organizando charlas con grupos de jóvenes, "en plan de mesa redonda, donde cada cual exponía aquellos problemas que más le podían interesar ${ }^{77}$

Con todo, debemos subrayar que estos intentos de renovar el programa misional constituyeron casos aislados dentro de la práctica habitual de la Asesoría Eclesiástica de Sindicatos, la cual fomentó hasta el final de su existencia el modelo tradicional. Las escenas vividas en 1971 en la misión llevada a cabo en la localidad zamorana de Pedrazales, en la comarca de Sanabria, así lo atestiguan:

El recibimiento se puede calificar de apoteósico, pues a pesar de ignorar el pueblo la hora exacta de la llegada del misionero, la gente, siguiendo instrucciones de su celosísimo párroco, estaba por las afueras del pueblo, esperando, y al repique de campanas acudió

\footnotetext{
75 AGA, AES, 1960, Caja 23-3.

76 AGA, AES, 1970, Caja 23-3.

77 AGA, AES, 1972, Caja 24-2.
} 
todo el vecindario, no quedando en casa nada más que los enfermos, según informe y recuento que hizo el Sr. Alcalde. [...]

Los actos generales que se han tenido han sido: Ofrecimiento de obras; Rosario con misa y homilía sobre los Sacramentos; Misión especial para los niños a las once y media de la mañana; por la noche el acto general para toda clase de personas, acto básico de la Santa Misión. En los últimos días tuve conferencias particulares para jóvenes, aunque sólo había media docena de ellas y unas conferencias especiales para hombres y mujeres.

El Temario desarrollado en la Santa Misión ha sido el tradicional: Pláticas doctrinales. Sobre los mandamientos. Sermones morales. Sobre el pecado y verdades eternas. [...]

No quedó ni un fiel sin confesar y comulgar. Además, hubo la nota simpática de que los niños... comulgaron todos los días hasta finalizar la Santa Misión, pidiendo por el éxito de la misma. También algunos hombres y mujeres comulgaron todos los días. Los días 24 y 25 de abril ya comulgó todo el pueblo. ${ }^{78}$

El relato de lo ocurrido en Pedrazales no se diferenciaba en lo más mínimo de las crónicas misionales de la primera mitad de la década de 1940 y ejemplificaba el afán de la Asesoría por perpetuar los métodos tradicionales. No obstante, en el contexto de la España de inicios de la década de 1970 ese tipo de métodos empezaban a resultar viables únicamente en comarcas económicamente deprimidas y fuertemente afectadas por la emigración, como la de Sanabria, donde los cambios sociales y culturales iniciados diez años antes se habían dejado sentir menos y donde una población sensiblemente envejecida era aún susceptible de dar una respuesta positiva a los mismos.

\section{RECUPERANDO A LA CLASE OBRERA: MISIONES Y ACTITUDES POLÍTICAS}

Las misiones de la Asesoría Eclesiástica de Sindicatos tenían como uno de sus objetivos primordiales llevar el mensaje católico a la clase obrera. No obstante, en absoluto debemos considerarlas como campañas religiosas específicamente dirigidas a los obreros. Se trataba de campañas generales dirigidas a la totalidad de la población de una determinada localidad, independientemente de su clase social, en las que, eso sí, se prestaba una atención específica a los obreros, mediante una serie de actos dirigidos exclusivamente a ellos.

Todos los misioneros partían de la premisa de que los obreros constituían el sector de la sociedad al que más difícil resultaba implicar en la misión. La Asesoría compartía plenamente la «teoría de la apostasía obrera» que la mayoría del clero español había hecho suya. Según esta interpretación, en un momento dado del desarrollo histórico español, posiblemente durante la segunda mitad del siglo XIX, los obreros se habían apartado mayoritariamente de la religión, produciéndose una amarga ruptura en una sociedad que tradicionalmente había sido unánimemente católica. La responsabilidad de dicha ruptura era achacable a la influencia que las ideologías y organizaciones izquierdistas y anticlericales habían ejercido sobre la masa obrera de manera continuada durante décadas. Esta «apostasía» había terminado por llevar a una mayoría de la clase obrera a

78 AGA, AES, 1971, Caja 23-3. interiorizar posiciones refractarias al hecho eclesiástico. ${ }^{79} \mathrm{El}$ obrero medio español, según lo concebía la Asesoría era un hombre aficionado a la blasfemia, Ileno de prejuicios hacia los curas y que pensaba que si era visto entrando en una iglesia por sus amigos sería víctima de bromas por parte de éstos. ${ }^{80}$ Existía un conflicto entre la cultura eclesiástica y la cultura obrera que obstaculizaba el que las misiones fuesen eficaces a la hora de inculcar el mensaje católico a la clase obrera.

La dificultad de movilizar a los obreros fue comprobada por la Asesoría en una de las primeras campañas misionales que llevó a cabo: la realizada en la cuenca minera de La Unión, en la provincia de Murcia, en 1949. En esta campaña no se organizaron actos específicos para los obreros en sus centros de trabajo, sino que se les animó, mediante una campaña de propaganda, a que acudieran a los actos generales organizados para el común de la población. ${ }^{81} \mathrm{El}$ resultado fue que la mayoría de la población obrera no asistió a los actos misionales, desarrollándose éstos con un público formado básicamente por mujeres, niños y algunos profesionales de clase media que eran asistentes habituales a misa. ${ }^{82}$

La Asesoría extrajo de esta experiencia una lección que nunca olvidaría: no se podía esperar que los obreros acudieran por propia iniciativa a la misión, sino que era ésta la que debía ir a buscarlos. En adelante, todas las campañas misionales contemplaron la organización de actos específicos para obreros a realizar en los propios centros de trabajo y durante el horario laboral, considerándose que ésta era la única forma de garantizar que la población obrera escuchase el mensaje misional. Para organizar dichos actos resultaba imprescindible contar con la colaboración de los directores de las empresas concernidas. Los misioneros debían solicitarles autorización para dar a los empleados una charla de aproximadamente una hora de duración. La empresa debía comprometerse a «regalar» esa hora a los empleados, remunerándola y no exigiendo su recuperación, pues de lo contrario los obreros recibirían a los misioneros con hostilidad. En una abrumadora mayoría de los casos, los directores de las empresas colaboraban. Algunos directores iban más allá y se sumaban al clima de entusiasmo misional, adoptando medidas favorecedoras del mismo, tales como ofrecer a sus empleados un desayuno gratis, regalarles ejemplares de encíclicas papales o realizar donativos a la Asesoría para ayudar a costear la misión. ${ }^{83}$ En último

79 Para un análisis general de la "teoría de la apostasía obrera», basado en los testimonios de uno de sus defensores, el misionero redentorista Ramón Sarabia, así como de otros autores que introdujeron matizaciones en la misma - por incorporar un elemento de autocrítica que hacía hincapié en la idea de que determinadas actitudes eclesiásticas habían contribuido a la desafección de los obreros-, tales como los sacerdotes Francisco Peiró y Maximiliano Arboleya, véase: Arbeloa 1975: 87-112 y 133-143.

80 AGA, AES, 1950, Caja 26.

81 Se difundieron octavillas con textos como el que sigue: "SANTA MISIÓN. NOVIEMBRE 1949. No te venza la pereza, no te retraiga el respeto humano. Por la paz de tu alma, por tu bien eterno. Por la seguridad de la salvación de tu alma. NO DEJES DE ASISTIR A LAS MISIONES»: AGA, AES, 1949, Caja 25.

82 AGA, AES, 1949, Caja 25.

83 En 1950 las empresas Minas de Rodalquilar y Minas de Almagrera - ambas pertenecientes al grupo del Instituto Nacional de Industriafinanciaron el coste total de los actos misionales llevados a cabo por la Asesoría en Rodalquilar y Sierra Almagrera: Boletín de Información..., no 6 y 10,1951 y 1952. 
extremo, las empresas que no deseaban «regalar» la hora solían facilitar que, al menos, los misioneros pudieran hablar a los empleados durante los cambios de turno o unos momentos antes de la entrada o la salida del tajo.

La práctica de misionar a los obreros en el mismo centro de trabajo sirvió para que no se volviese a repetir el fracaso vivido en La Unión en 1949. La nueva campaña misional llevada a cabo en 1961 en la misma zona de La Unión y en Cartagena reveló cómo el cambio de método garantizaba una mejora en los resultados. En esta ocasión, la Asesoría preparó concienzudamente los actos específicos dirigidos a los obreros, elaborando un censo de todas las empresas que empleaban a más de cincuenta trabajadores y contactando a sus directores para que autorizasen la entrada de los misioneros en sus instalaciones. Éstos mostraron su total predisposición a colaborar y algunos de ellos concedieron una paga extraordinaria a los empleados, como forma de festejar la misión. En total se celebraron actos en 49 empresas, ubicadas en los municipios de Cartagena, La Unión y Mazarrón, las cuales sumaban un censo laboral de 13.276 empleados. ${ }^{84}$ A diferencia de lo ocurrido en 1949 , la misión fue valorada como un éxito.

Recurrir a la colaboración de los directores de empresas garantizaba que los obreros recibiesen el mensaje misional pero, al mismo tiempo, planteaba una serie de problemas que podían llegar a comprometer la eficacia del mismo. En primer lugar, podía quedar comprometido el carácter voluntario de la asistencia a los actos. Comoquiera que el director de empresa había participado en la organización del acto, los obreros podían entender que éste deseaba que acudiesen al mismo. Los organizadores de las misiones eran conscientes de que la asistencia de los obreros no siempre era libre, pero preferían no profundizar en esta cuestión, limitándose a recomendar que se evitasen situaciones tensas. ${ }^{85}$

En segundo lugar, el que el misionero apareciese en las instalaciones de la empresa de la mano del director podía generar una reacción negativa de los obreros, sobre todo si éstos estaban atravesando por una etapa de descontento laboral. Además, la asociación entre misionero y empresario reforzaba la idea, sólidamente asentada en el imaginario de la clase obrera, de la Iglesia como una institución colaboradora del poder económico. Tras la misión llevada a cabo en la cuenca minera de Palencia en 1958 el misionero dominico que intervino en Barruelo de Santullán realizó un lúcido informe en el que ponía de relieve la dificultad de atraer a los obreros si el clero continuaba apareciendo ante sus ojos como un aliado de las empresas. En concreto, señalaba que existía un gran descontento entre los mineros que trabajaban para la empresa Sociedad de Minas de Barruelo debido a que consideraban sus salarios insuficientes. Desde un punto de vista religioso, esta situación resultaba negativa, dado que, según el misionero, los mineros estaban convencidos de que la Iglesia poseía influencia para arrancar de la empresa las mejoras salariales que deseaban y si no lo hacía era por su «connivencia» con la misma. El hecho de

\footnotetext{
84 AGA, AES, 1961, Caja 23-3.

85 Así, se recomendaba a los misioneros que cuando celebrasen una misa intentasen que los directivos de la empresa no estuviesen presentes, de modo que éstos no pudiesen saber quiénes habían comulgado y quiénes no: Congreso 1961: 60.
}

que la dirección de la empresa prestase apoyo económico a todas las iniciativas del párroco contribuía a reforzar esa identificación entre poder eclesiástico y poder empresarial. ${ }^{86}$ A pesar de advertencias de este tipo, la Asesoría no alteró sus métodos y la práctica de concordar con los directores de empresa la organización de actos en los centros de trabajo siguió estando presente en la mayoría de sus misiones.

La Asesoría comprobó, además, que el que los obreros escuchasen a los misioneros durante los actos programados en sus centros de trabajo no se traducía, necesariamente, en una mayor participación de aquéllos en los demás actos misionales, los denominados "actos generales», que eran programados para la totalidad de la población. Así, en la misión celebrada en Ferrol en 1960 se constató que la mayoría de los obreros no asistió a los actos generales, escuchando la predicación de los misioneros únicamente en los actos específicos, programados en los centros de trabajo. De este modo, a los actos generales sólo asistieron "los de siempre», la población que mantenía la costumbre de asistir a misa los domingos. La misión perdía, de este modo, su carácter de instrumento para la reconquista de las masas alejadas de la Iglesia, convirtiéndose en una mera reafirmación de una estructura religiosa dada. ${ }^{87}$ En la cuenca minera de Peñarroya-Pueblonuevo, en 1964, se volvió a vivir una situación similar. Los obreros fueron misionados en actos celebrados en las instalaciones de las empresas de la zona, tales como Empresa Nacional Carbonífera del Sur (ENCASUR), Sociedad Minera y Metalúrgica de Peñarroya o Unión Española de Explosivos, pero se echó en falta su presencia en los actos generales. ${ }^{88}$

Los actos misionales para obreros organizados por la Asesoría se caracterizaban por su total ausencia de contenido social. Antes del inicio de cada misión los misioneros que iban a participar en ella recibían de la Asesoría un documento de «instrucciones» en el cual figuraba indefectiblemente el siguiente texto:

Tengan en cuenta los Padres Misioneros que los temas que han de tratar son los tradicionales. Aun en las conferencias que dirijan a los obreros en los centros de trabajo han de versar sobre temas religiosos. Eviten el tema social: tan sólo para explicarlo cuando sea necesario para aclarar los deberes propios contenidos en los Mandamientos de la ley de Dios o de la Iglesia. ${ }^{89}$

Este texto apareció por primera vez en las primeras campañas misionales organizadas en 1949 y seguía apareciendo en las últimas, en 1972. A través de él, y de su persistencia en el tiempo, se evidencia el contenido fuertemente conservador de la visión social de la Asesoría. Así las cosas, el contenido de los actos misionales para obreros parece haberse caracterizado por buscar una reacción emotiva por parte del auditorio. Los misioneros alababan a los obreros por la «dureza» de su trabajo, pero al mismo tiempo les recordaban que nada de ello tenía verdadero valor si no iba acompañado de una sincera conversión religiosa. Al fin y al cabo Jesucristo también había

\footnotetext{
86 AGA, AES, 1958, Caja 24-3.

87 AGA, AES, 1960, Caja 23-2. Algunas notas sobre la actividad misional en Galicia en estos años en: Rodríguez Lago 2004: 345-348.

88 AGA, AES, 1964, Caja 23-1.

89 AGA, AES, s.f., Caja 10.
} 
sido un obrero..$^{90}$ Las crónicas misionales constataban que, en ocasiones, este discurso lograba generar un ambiente de emotividad. Así, en 1950 se aseguraba que un misionero había logrado entusiasmar a un grupo de mineros de Mieres:

Al decirles un día el Misionero ponderando lo duro de su trabajo: «Si esto lo hicierais en estado de gracia de Dios y con espíritu sobrenatural, los mineros estarían en el cielo ocupando los primeros lugares», prorrumpieron en un cerrado «iViva el Misionero-minero!», que conmovió a éste, hasta hacerle casi llorar. ${ }^{91}$

En otros muchos casos la estrategia no debió funcionar. Así, en 1959 se reconocía que, en más de una ocasión, los misioneros que habían visitado pozos mineros habían recibido respuestas tales como: «Oiga usted, señor cura, no nos haga perder el tiempo. Si no trae usted un aumento del jornal no nos vale usted para maldita la cosa».92

El que no hablasen de "cosas sociales» no quiere decir que los misioneros fuesen insensibles a la problemática social de las comunidades que visitaban. Muy al contrario, durante la década de 1950 los informes que enviaron a la Asesoría reflejaron el ambiente de pobreza que caracterizaba la vida de muchos españoles. Así, en 1959 el capuchino que llevó a cabo la misión en la localidad leonesa de Sotillos de Sabero solicitaba al Secretario de la Sección de Apostolado de la Asesoría, Teodomiro de Villalobos, que utilizase sus contactos para intentar solucionar los problemas sociales de la localidad:

Respecto del trabajo en las minas, ¿qué quiere que le diga? ... Que lo considero brutalmente peligroso y escasamente retribuido... En lo que va de año han perecido en las entrañas de la mina nada menos que 17 obreros y se han accidentado una infinidad... Esto da pie para pensar que las condiciones laborales de los mineros son deplorables; pues de lo contrario, no se darían tantas desgracias... Agregue a esto la SILICOSIS y otras enfermedades, a que están necesariamente expuestos los mineros... Y total, iel sueldo base de unas 35 a 42 pesetas! ... ¿ ¿No le parece una verdadera mezquindad?

Soy del parecer que URGE DE NECESIDAD UNA INSPECCIÓN RIGUROSA de sueldos y de CONDICIONES DE TRABAJO... De no remediarse tales y tan imperiosas necesidades y de no remediárselas con urgencia, se corre el riesgo, no sólo de perderse el fruto de la santa misión, sino de sobrevengan sucesos muy desagradables, que todos lamentaríamos con amargura. iPadre Teodomiro, eche una mano a esos pobres mineros y verá cómo se los atrae hacia Cristo! ${ }^{93}$

Durante la década de 1960, en un contexto de crecimiento económico y de mejoras en los estándares de vida de la población, los misioneros se esforzaron en poner de relieve los problemas de aquellos grupos sociales que no se estaban beneficiando del desarrollo, con especial atención a los habitantes de barriadas marginales. Así,

90 La imagen de «Jesús obrero» era una de las ideas fuerza del mensaje misional. Así una octavilla impresa para la misión de Ferrol rezaba: «iOBRERO! ¿Sabes lo que es la SANTA MISIÓN? Es la palabra de JESÚS. Es la solución de tus problemas espirituales, que tienes, aunque lo niegues. JESÚS es un obrero como tú. Conoce tus problemas. Aclarará tus dudas. Iluminará tu alma. ¡Escúchale!»: AGA, AES, 1960, Caja 10.

91 Boletín de Información..., no 5, 1951.

92 AGA, AES, 1959, Caja 23-3.

93 AGA, AES, 1959, Caja 23-3. por ejemplo, durante la campaña misional llevada a cabo en la costa de la provincia de Almería en 1967 tuvieron muy presente la situación de determinados barrios de pescadores empobrecidos, como el de Cavite, en Adra, donde denunciaban que los niños pasaban todo el día en la calle, «revolviendo escombros, desperdicios, latas y detritus». ${ }^{94}$ Los misioneros poseían un interés sincero por los problemas sociales de las poblaciones a las que visitaban, pero el mismo no fue expresado dotando de un contenido social a sus predicaciones, sino que fue derivado a través de sus comunicaciones internas con la Asesoría, de la cual esperaban que iniciase gestiones destinadas a paliar las situaciones de necesidad que habían contemplado.

Inevitablemente, las relaciones de los misioneros con la población obrera estaban determinadas también por factores políticos. La misión se presentaba a sí misma como un acontecimiento religioso, desprovisto de cualquier connotación política, pero resultaba evidente que tanto el contexto como el pasado político de las poblaciones misionadas influían en el desarrollo de la misma.

Las localidades con un fuerte pasado izquierdista resultaban difíciles de misionar, pues en ellas siempre se encontraban latentes los prejuicios contra la Iglesia $y$, aunque de forma soterrada, era fácil que éstos se manifestasen durante los días de la misión. En 1960, ante la campaña que se iba a llevar a cabo en la provincia de Santander, los misioneros que debían actuar en Reinosa, El Astillero y Camargo fueron advertidos de que se trataba de núcleos que habían sido "muy socialistas» en el pasado y en los que las actitudes de indiferencia hacia la religión estaban muy extendidas. El recuerdo de la Guerra Civil seguía vigente y la presencia de antiguos presos políticos - «excarcelados»- ejercía una influencia negativa sobre el conjunto de la población. El resultado de la campaña vino a confirmar los poco halagüeños antecedentes. Los actos misionales contaron con una nutrida presencia de mujeres, jóvenes y niños, pero la asistencia de hombres adultos fue sensiblemente más baja y se reconoció que la misión había tenido escaso impacto en los "ambientes fabriles». ${ }^{95}$

Una dinámica similar vamos a observar en la repetidamente mencionada misión de la cuenca minera de Peñarroya-Pueblonuevo, de 1964. La Asesoría informó a los misioneros de que los resentimientos ligados a la Guerra Civil se encontraban todavía a flor de piel en la comarca. La cuenca minera había formado parte de la zona republicana desde el estallido de la contienda hasta octubre de 1936, período durante el cual se habían producido encarcelamientos y fusilamientos de personas consideradas derechistas. Tras la entrada de las tropas franquistas se produjeron varios episodios de represión antirrepublicana que se concretaron en fusilamientos y condenas a cárcel de vecinos considerados izquierdistas. ${ }^{96}$ A la altura de 1964 muchas familias seguían teniendo presentes los traumáticos acontecimientos de aquellos años y los mismos condicionaban su percepción no sólo de la política, sino también de la religión. Los familiares de quienes habían sufrido la represión antirrepublicana tendían a identificar a la Iglesia con el régimen franquista,

\footnotetext{
94 AGA, AES, 1967, Caja 23-1.

95 AGA, AES, 1960, Caja 23-3.

96 Véase: López Mohedano 2004: 39-230.
} 
lo cual se traducía en el mantenimiento de actitudes de desapego hacia la vida eclesiástica. La Asesoría prevenía a los misioneros, de una manera especial, sobre Los Blázquez, municipio que por entonces contaba con 1.834 habitantes y al que se conceptuaba como el "peor», desde el punto de vista religioso, de toda la comarca, asegurándose que los párrocos que habían pasado por el mismo habían "sufrido mucho». ${ }^{97}$

En cierto modo, la campaña misional celebrada en 1964 buscaba cerrar las heridas procedentes de la Guerra Civil que aún pervivían. En la carta abierta que el Obispo de Córdoba dirigió a los fieles pocos días antes del inicio de la misión para animarles a participar en la misma se aludía a la necesidad de "olvidar ofensas y rencores», lo que puede interpretarse como una referencia a la herencia dejada por los años bélicos. ${ }^{98}$ No parece, sin embargo, que tal objetivo se lograse. La valoración que hicieron los misioneros sobre los resultados de la campaña misional de PeñarroyaPueblonuevo fue negativa. Los obreros de las empresas mineras e industriales existentes en la zona escucharon a los misioneros en los actos organizados en sus centros de trabajo, pero se abstuvieron mayoritariamente de participar en los actos generales. Los Blázquez confirmó su fama de pueblo irreligioso: en él ni siquiera se consiguió una movilización significativa de las mujeres, un público con el que siempre contaban los misioneros. El religioso capuchino que se encargó de misionar El Hoyo de Belmez, pedanía del municipio de Belmez, creyó encontrar la explicación de la frialdad mostrada hacia los misioneros: buena parte de la población no había olvidado aún los fusilamientos acaecidos durante la Guerra Civil. El problema radicaba en que realizaban una identificación entre el régimen franquista y la Iglesia católica, considerando que esta última era también responsable de aquellas muertes. ${ }^{99}$

\section{MISIONES Y CONFLICTIVIDAD: LA «OPOSICIÓN A LA MISIÓN»}

La existencia de una interrelación entre política y misiones llevaba a que, en ocasiones, éstas fuesen objeto de actos de rechazo e, incluso, de boicot. Es lo que en el argot de los misioneros se conocía como «oposición a la misión». Se trataba de un problema que se había planteado ya en la segunda mitad del siglo XIX, cuando desde posicionamientos liberales, republicanos y anticlericales se había asociado a las misiones con estrategias del clero para combatir el ordenamiento político liberal. Esta asociación había provocado que las misiones tuvieran que hacer frente, en muchas ocasiones, a manifestaciones organizadas de repudio que terminaron derivando en violencia. La violencia anti-misional fue asumida por las organizaciones obreras socialistas y anarcosindicalistas y llegaría a su paroxismo durante la II República, período en el cual la actividad de los misioneros quedó prácticamente suspendida, debido a la violenta oposición de las susodichas organizaciones.

Finalizada la Guerra Civil, la oposición a la que el movimiento misional venía haciendo frente desde mediados del siglo XIX fue completamente removida. La proscripción de la vida pública de aquellas organizaciones que habían

\footnotetext{
97 AGA, AES, 1964, Caja, 24-1.

98 AGA, AES, 1964, Caja 23-1.

99 AGA, AES, 1964, Caja 23-1.
}

alimentado los comportamientos anticlericales garantizaba que las misiones pudieran discurrir por las calles de ciudades y pueblos sin temor a ser objeto de ataques violentos. No obstante, la «oposición a la misión» no desapareció del todo. De una manera subrepticia, se siguieron produciendo actos de hostilidad. Existía toda una tradición de intolerancia anticlerical que no se expresaba abiertamente, pero que aprovechaba cualquier resquicio para dejar constancia de su persistencia.

Los testimonios al respecto son numerosos. En las misiones desarrolladas por los jesuitas en Andalucía durante la década de 1940 se produjeron varios casos de este tipo, pero hay uno de ellos que resulta especialmente llamativo: la profanación de un crucifijo, aprovechando el anonimato de la noche, durante una misión celebrada en la localidad malagueña de Arriate en 1943. Se había colocado un crucifijo de grandes dimensiones en un promontorio cercano al pueblo: la «cruz de la misión». Pero al día siguiente un hecho imprevisto conmocionó a todos:

Al amanecer se dieron cuenta algunos de que la cruz había sido arrancada de su sitio, las autoridades comenzaron a hacer pesquisas que no dieron resultado y vinieron todas a manifestarnos su pesar. Se tuvo la comunión general y entretanto muchos se dedicaron a recorrer los alrededores para ver si descubrían algo. Cuatro niñas fueron las afortunadas; después de recorrer muchísimo terreno encontraron la cruz intacta metida en una alcantarilla. La mayor tendría sus buenos doce años; la cogieron y con no pequeños trabajos la llevaron al sitio donde estaba. Vinieron jadeantes pero llenas de alegría a darme cuenta del hallazgo. Al terminar la Misa de comunión salimos las Autoridades y los Padres Misioneros camino del monte donde estaba la cruz; nada dijimos pero el pueblo entero se vino. Bendije la cruz profanada y el Sr. Alcalde y el Comandante de puesto la colocaron en su sitio; les hablé y fueron pasando todos besando la cruz. ${ }^{100}$

Se trataba de un llamativo acto sacrílego cometido apenas cuatro años después del final de la Guerra Civil, en un pueblo donde el movimiento obrero había gozado de una gran fortaleza y donde la violencia anticlerical se había manifestado en diferentes ocasiones, tanto durante los años de la contienda como con anterioridad a la misma.

Durante las misiones llevadas a cabo por la Asesoría Eclesiástica de Sindicatos a partir de 1949 no vamos a encontrar ataques anticlericales tan impactantes como el descrito, pero sívamos a asistir a manifestaciones recurrentes de «oposición a la misión». Una de las formas más simples de esta "oposición» va a ser la difusión de comentarios críticos. En ocasiones, los misioneros constataban que su llegada se veía acompañada de la circulación de "chismes» que buscaban deteriorar su imagen ante el conjunto de la población. A menudo, consideraban que los mismos no habían surgido espontáneamente, sino que eran producto de una «campaña organizada». Durante la década de 1950 y en los primeros años de la década de 1960 fue habitual que tales comentarios incidiesen en la idea de que las misiones eran organizadas "por el Gobierno» para neutralizar las consecuencias políticas de la situación de crisis económica en la que estaba sumido el país. Así, en 1952 durante la

100 Copado 1973: 206. 
campaña celebrada en la provincia de Santander se constató que "antiguos líderes sociales» habían incitado a no acudir a la misión, debido a que ésta poseía un «carácter político». ${ }^{101}$ En 1955, en la comarca de El Bierzo, en la provincia de León, fueron interceptadas «hojas clandestinas» contra la misión. Las autoridades no lograron individuar a los responsables, lo cual causó desconcierto entre los misioneros. ${ }^{102} Y$ en 1959, durante la campaña desarrollada en la cuenca minera de León, se difundieron comentarios que resaltaban la idea de que la misión era "una medida de apaciguamiento del Gobierno en las difíciles circunstancias actuales». ${ }^{103}$

En ocasiones, la «oposición a la misión» adoptó la forma de «bulos» que afirmaban que la llegada de los misioneros comportaba algún tipo de perjuicio para la población. Así, durante la campaña realizada en 1958 en la cuenca minera de Palencia se difundió la información falsa de que a todos los trabajadores por cuenta ajena se les iba a descontar 25 pesetas del salario en concepto de "limosna al misionero». Al parecer, este rumor circuló con especial intensidad en la localidad de Guardo, donde la asistencia a la misión fue cifrada entre un 65 y un 70\%, un porcentaje sensiblemente inferior al del resto de localidades. ${ }^{104}$ Las actitudes contrarias a la misión también podían generar tensiones en el interior de la vida familiar. Así, en Ferrol, en 1960, hubo hombres que prohibieron a sus esposas e hijos acudir a la misión, llegando a castigar a estos últimos por haberlo hecho. En la misión de Ferrol se produjeron, por lo demás, incidentes que fueron más allá del comentario pronunciado en voz baja. Durante la madrugada de la primera jornada un grupo de hombres recorrió la localidad «cantando cosas obscenas y profiriendo frases de insulto contra los misioneros». Éstos no creyeron que se tratase de una simple broma de borrachos y lo atribuyeron a una verdadera «oposición organizada». ${ }^{105}$

Ese mismo año la Asesoría llevó a cabo su campaña misional en localidades industriales de la provincia de Santander y aquí iba a encontrar una oposición inesperada, en la medida que procedía de otra organización vinculada a la Iglesia: la Hermandad Obrera de Acción Católica (HOAC). Uno de los momentos estrella de esta campaña debía ser un acto para obreros a celebrar en las instalaciones de la Sociedad Española de Construcción Naval, en Reinosa. El ambiente en esta empresa estaba enrarecido, debido a que se habían producido unos despidos. Días antes de la celebración del acto misional la HOAC distribuyó entre los obreros unas octavillas en las que se criticaba que se llevase a cabo un acto religioso organizado por los sindicatos oficiales, los cuales no habían resultado eficaces a la hora de evitar los despidos. No resultaba coherente que quienes no habían ayudado a los trabajadores a conservar sus puestos de trabajo apareciesen ahora para intentar evangelizarlos. La crítica de la HOAC se basaba en el hecho de que la misión estaba organizada por la Asesoría y de que ésta se encontraba orgánicamente vinculada al sindicalismo oficial. El carácter de las octavillas fue juzgado como "característico de la HOAC», es decir, «chocante» pero "sin

\footnotetext{
101 Boletín de Información..., no 13, 1953.

102 Boletín de Información..., n 26, 1956.

103 AGA, AES, 1959, Caja 23-3.

104 AGA, AES, 1958, Caja 24-3.

105 AGA, AES, 1960, Caja 23-2.
}

llegar a subversivo». En cualquier caso, en previsión de que las mismas provocasen algún incidente, no se llevó a cabo ningún acto en la Naval y los misioneros se limitaron a realizar una breve visita a sus instalaciones. Al margen de este incidente, el resto de actos misionales programados en Reinosa se desarrollaron con normalidad, si bien la asistencia de población obrera a los mismos fue considerada muy baja. ${ }^{106}$

Las relaciones entre la Asesoría Eclesiástica de Sindicatos y la HOAC estuvieron marcadas por la tensión en numerosas ocasiones. La HOAC había sido creada en 1946 como una rama especializada de Acción Católica dedicada al apostolado obrero. No obstante, algunos sectores de la jerarquía eclesiástica la concibieron también como un punto de partida para el futuro desarrollo de un sindicato, en el caso de que algún día el régimen decidiese retirar a los falangistas el monopolio sindical que les había otorgado y permitir alguna forma de pluralismo sindical limitado. ${ }^{107}$ Este carácter de plataforma para-sindical alarmó a los jerarcas del sindicalismo vertical, quienes consideraron «innecesaria» la nueva organización, en la medida que - según ellosla labor de apostolado obrero ya era llevada a cabo por la Asesoría - creada dos años antes - y en la medida que el sindicalismo vertical venía a recoger fielmente la herencia del sindicalismo católico, hasta el punto que podía aspirar a ser reconocido como «católico». ${ }^{108}$

A pesar de estar vinculada al sindicalismo vertical, la Asesoría no compartió inicialmente sus prejuicios hacia la HOAC. Muy al contrario, los Asesores saludaron su creación como una iniciativa saludable que venía a reforzar los esfuerzos por reconducir a la clase obrera hacia la fe católica. Así, en algunas Asesorías Provinciales se estableció la práctica de animar a los obreros que se acercaban a sus oficinas a unirse a la nueva rama de Acción Católica. Desde la Asesoría se pensaba que era posible desarrollar una sinergia entre ambas organizaciones. ${ }^{109}$

Sin embargo, pronto se puso de manifiesto que dicha colaboración resultaba imposible. La HOAC se fue decantando por un modelo de apostolado de fuerte impronta social que no renunciaba a lanzar críticas contra la carestía de la vida o los bajos salarios. Esta forma de concebir el catolicismo social contrastaba con la estrategia seguida por la Asesoría, que conminaba a sus misioneros a «evitar el tema social». Al mismo tiempo, la HOAC trató de marcar distancias con

106 AGA, AES, 1960, Caja 23-3.

107 Montero 2015: 153.

108 Desde la Asesoría se dio sustento a esta interpretación. Así, uno de sus más destacados colaboradores, el jesuita Martín Brugarola, difundió la tesis de que el sindicalismo vertical era católico: Brugarola 1955. Esta tesis distaba mucho de ser aceptada por toda la Iglesia española, dentro de la cual existían sectores que lamentaban que el régimen no hubiese permitido la existencia de un sindicato católico, diferenciado del falangista, y que, en todo caso, consideraban peligroso el conceder al sindicalismo vertical el marchamo de "católico», dado que ello provocaría un rechazo al catolicismo por parte de los obreros que estaban descontentos con el modelo de organización verticalista.

109 Esta voluntad de cooperación es muy evidente en la Segunda Reunión de Asesores Eclesiásticos, celebrada en 1946, poco después de la creación de la HOAC: Asesoría Eclesiástica Nacional de Sindicatos 1946: 20. María Silvia López Gallego enfatiza estas colaboraciones, pero, a mi juicio, descuida el hecho fundamental de que la Asesoría y HOAC terminaron suponiendo modelos antitéticos de apostolado: López Gallego 2004: 680-682. 
respecto al régimen franquista, evitando que ninguna de sus iniciativas pudiera servir para reforzar la asociación Iglesiarégimen, que tan firmemente asentada se encontraba en la mentalidad de muchos obreros. ${ }^{110}$ Ello implicaba adoptar un posicionamiento crítico respecto a los sindicatos oficiales -a los que acusaba de apropiarse indebidamente de la condición de «católicos»- y muy especialmente hacia la Asesoría, que era la principal baza utilizada por los dirigentes verticalistas para sustentar dicha condición.

Las hostilidades entre ambas entidades terminaron por plantearse de manera abierta a raíz del radio-mensaje que el Papa Pío XII dirigió a los trabajadores españoles el 11 de marzo de 1951. Los sindicatos verticales, en estrecha colaboración con la Asesoría Eclesiástica, organizaron actos públicos por toda la geografía española para llevar a cabo escuchas colectivas del mensaje papal. El objetivo era presentar la alocución del Santo Padre como un aval a la supuesta catolicidad del sindicalismo oficial. Por su parte, la HOAC boicoteó estos actos, organizando sus propias concentraciones, nítidamente separadas de las oficiales. Su objetivo era subrayar que el Papa se estaba dirigiendo "a los trabajadores españoles», pero no "a los sindicatos oficiales». Como consecuencia de ello, en varias ciudades las concentraciones oficiales se saldaron con un llamativo fracaso de asistencia. Este hecho causó un profundo malestar entre los sacerdotes que colaboraban con la Asesoría y contribuyó, de manera determinante, a predisponerlos contra la HOAC. ${ }^{111}$

La buena predisposición que la Asesoría había mostrado inicialmente hacia la HOAC desapareció, imponiéndose un clima de desconfianza mutua que, en ocasiones, pudo derivar en situaciones de conflicto, como ocurrió en la Naval de Reinosa en 1960. En 1961 un boletín reservado de noticias que circulaba entre los sacerdotes de la Asesoría analizaba la polémica epistolar que, el año anterior, habían mantenido el Cardenal Primado de España, Enrique Pla y Deniel y el Ministro Secretario General del Movimiento, José Solís, con motivo de las actividades de la HOAC, las cuales habían sido censuradas por el ministro y defendidas por el prelado. ${ }^{112}$ La Asesoría, lógicamente, intentaba suavizar la polémica, asegurando que los posicionamientos del dirigente eclesiástico y el político eran, en realidad, «muy cercanos el uno del otro». Pero no desaprovechaba la ocasión para arremeter contra "algunos dirigentes de la HOAC» que se comportaban como enemigos del régimen franquista. La HOAC era presentada, además, como una organización que, merced a su «demagogia», conseguía una repercusión social muy superior a su verdadera importancia numérica y a la entidad de la labor de apostolado que desempeñaba, dado que otras entidades de corte tradicionalista, como las Hermandades del Trabajo o la propia Asesoría, desarrollaban una labor «mucho más intensa». ${ }^{113}$

110 Sobre las diferencias irreconciliables que existían entre el modelo de apostolado propuesto por la HOAC y el sostenido por la Asesoría, véase: Berzal de la Rosa 2015: 181-214.

111 AGA, AES, 1951, Caja 27. También: Bernal García 2010: 194

112 Sobre la polémica entre Pla y Deniel y Solís, véase: Blázquez 1991: 132-133. Sobre la HOAC en general, véase especialmente: López García 1995; Murcia 1995.

113 El boletín aseguraba que durante la I Asamblea de Pastoral Socia celebrada en Madrid en 1961 el Consiliario Nacional de las Hermandades del Trabajo había increpado al de la HOAC en los siguientes términos:
ASISTENCIA A LAS MISIONES, CONFESIONES Y COMUNIONES. ¿HUBO UNA VERDADERA RECATOLIZACIÓN?

Como hemos ido observando, las misiones perseguían una multiplicidad de objetivos de naturaleza religiosa, tales como bautizar a los no bautizados y administrar la primera comunión a quienes no la habían recibido; casar a los amancebados y lograr una moralización general de la vida pública; o difundir los planteamientos eclesiásticos entre la clase obrera, logrando que ésta abandonase sus tradicionales prejuicios anticlericales. No obstante, todos estos objetivos resultaban secundarios frente a lo que constituía el acto central de toda misión: lograr que el mayor número posible de habitantes de las localidades misionadas confesasen y comulgasen. Toda la misión estaba teleológicamente orientada hacia dicho objetivo, el cual debía conseguirse durante los últimos días de la misma, en el transcurso de una serie de actos generales que implicarían celebraciones masivas de la eucaristía.

Comoquiera que el objetivo último de las misiones era lograr que el mayor número posible de personas comulgasen, el grado de éxito o fracaso de cada una de ellas era evaluado en función del número de comuniones distribuidas. A tal fin, se esperaba que los misioneros consignasen en sus informes las cifras de comulgantes, como forma de transmitir si se había logrado el objetivo perseguido. Durante la décadas de 1950 muchos misioneros de la Asesoría Eclesiástica de Sindicatos no fueron rigurosos a la hora de contabilizar las comuniones distribuidas, limitándose a señalar si habían sido "muchas» o "pocas». Pero desde comienzos de la década de 1960 los misioneros fueron exhortados a llevar una contabilidad rigurosa. Ello permitiría calcular el porcentaje que los comulgantes suponían sobre el total de "población obligada», es decir, sobre el número de habitantes de la localidad misionada que habían realizado la primera comunión. Se contabilizaría, además, el número de asistentes a los actos misionales, como forma de completar la visión global sobre lo que la misión había supuesto para la vida religiosa de la localidad misionada.

En base a estos datos, la Asesoría clasificaba la misión en una escala de éxito-fracaso que, básicamente, contemplaba tres situaciones posibles. La primera era lo que se denominaba "misión triunfalista», es decir, un éxito sin paliativos. La «misión triunfalista» implicaba una fuerte movilización religiosa de los habitantes de la localidad misionada. La asistencia a los actos organizados había sido masiva y éstos se habían saldado con abundantes confesiones y comuniones, muy superiores a las que se producían en un domingo normal. Los misioneros habían conectado con la población, siendo aclamados por ésta y recibiendo calurosas muestras de cariño. Al mismo tiempo, se habían producido "hechos edificantes y conmovedores»: personas notoriamente apartadas de la Iglesia que habían dado el paso de confesar y comulgar; amancebados que habían legalizado su convivencia mediante el sacramento

"¿Cuántos son ustedes? -Ocho mil- Pues nosotros solamente en Madrid somos 53.000 y no molestamos a nadie, y ustedes, ocho mil en toda España, no hacen más que herir a todo el mundo»; AGA, AES, Caja 10. Creadas en Madrid, en 1947, las Hermandades del Trabajo constituían otra organización de apostolado obrero de corte tradicionalista; véase: Redondo 1999: 926. 
del matrimonio... El siguiente relato, extraído de una crónica misional correspondiente a Villamayor de Campos (Zamora), en 1959, ejemplifica el ambiente de la «misión triunfalista»:

El recibimiento de los PP. Misioneros resultó muy hermoso por la nota pintoresca que ponían las banderas nacional y pontificia, que portaban cada uno de los niños de las escuelas que asistieron en masa con los señores maestros al frente. Todas las autoridades a quienes se había enviado invitación especial por parte de la parroquia asistieron en Corporación y saludaron con entusiasmo a los PP. Misioneros. Después de los saludos, se dirigió el pueblo a la iglesia parroquial cantando con entusiasmo cánticos de penitencia.

Tiene la parroquia una ermita a un kilómetro de distancia donde reside la Patrona, la Virgen del Socastro. Fue trasladada en procesión para presidir los actos misionales. No cabe duda que la devoción tan arraigada que el pueblo tiene a su excelsa Patrona ha contribuido enormemente al éxito de la santa misión.

Todos los actos generales han resultado impresionantes por la enorme afluencia de fieles, que llenaban las naves del hermoso templo recientemente inaugurado por el Sr. Obispo. Cada día se ha notado más entusiasmo en todos y se ha hecho lo imposible para poder compaginar las distintas ocupaciones con los actos de la misión. [...]

Las confesiones y comuniones, numerosas, se han ido sucediendo todos los días, culminando con la comunión general el Domingo día $9 .{ }^{114}$

Pero no siempre se conseguía una repercusión tan intensa. En ocasiones las misiones sólo lograban movilizar a ciertos sectores de la población. La asistencia a los actos misionales era sensiblemente superior a la propia de un domingo normal, pero se estaba lejos aún de lograr una confluencia unánime. Se hablaba entonces de «misión consoladora». Ésta había logrado una repercusión innegable en la vida local, si bien se había constatado que grupos sociales significativos habían continuado con sus actividades habituales, manteniéndose al margen. Los misioneros habían "caído bien» a los lugareños, pero no se habían producido muestras de entusiasmo desbordado. Ciertamente, se habían producido "hechos edificantes y conmovedores", pero no en la medida que a los misioneros les hubiese gustado: es posible que algún descreído recalcitrante les hubiese cerrado las puertas de su casa o que alguna pareja de amancebados hubiese evitado el sacramento del matrimonio. Si la «misión consoladora» se producía en una localidad caracterizada por bajos índices de práctica religiosa, en la que ya se sabía que la labor de los misioneros iba a ser complicada, no era considerada un fracaso. Antes bien, se la interpretaba como un alentador punto de partida. Los misioneros habían «sembrado la palabra de Dios" y, si en el futuro la localidad seguía siendo escenario de esfuerzos pastorales por parte del aparato eclesiástico, era muy factible que dicha siembra terminase por dar sus frutos.

La misión llevada a cabo en la cuenca minera de La Unión en 1951 vendría a responder plenamente a ese modelo "consolador». El tratarse de una zona donde los índices de práctica religiosa eran, de partida, muy bajos no propiciaba el desarrollo de una «misión triunfalista».
Además, la crisis que estaba atravesando la minería local y las duras condiciones de vida a las que se veían sometidos muchos de sus habitantes no contribuían a crear un clima propicio a la reconciliación con la Iglesia. Con todo, la misión no naufragó por completo: se consiguió un número decente de comuniones y, en opinión de los misioneros, se logró poner la primera piedra para la erección, en un futuro, de un edificio religioso más sólido:

Las primeras impresiones de los misioneros de La Unión, Portman, El Estrecho y El Llano de San Ginés fueron desoladoras: pueblos en gran parte destruidos, como si por ellos hubiera pasado una guerra asoladora. De 40.000 habitantes que tenía La Unión por los años 15 al 20, sólo cuenta hoy con unos 8.000 . Es que las minas de plomo argentífero, riquísimas en aquellos tiempos, cayeron verticalmente, y los habitantes de aquellos pueblos tuvieron que emigrar a otras regiones. [...]

En este ambiente de decaimiento y de miseria, bien se deja entender que las Misiones tenían que luchar con muchas dificultades. Es muy difícil el oír hablar de las verdades eternas con el estómago vacío y con horizontes muy oscuros por delante. Aparte de esto, en aquellos pueblos, en los años de su caída vertical, se había trabajado muy intensamente por la masonería, socialismo y comunismo para arrebatarles sus antiguas creencias religiosas. [...] No fueron estas Misiones de la cuenca minera de La Unión un desbordamiento de entusiasmo, pero tampoco en ellas se notó el frío glacial de que nos habían hablado. Pueblos hubo, como Portman, en que en masa acudían, hombres y mujeres, a todos los actos, confesando y comulgando más del 80 por ciento. Los señores Párrocos de La Unión quedaron muy satisfechos del éxito logrado, con grandes deseos de que se repitan frecuentemente estas Misiones hasta conseguir la completa recristianización de este pueblo. ${ }^{115}$

Pero junto con la «misión triunfalista» y la «consoladora» existía una tercera posibilidad: que la misión fracasase. Entre los misioneros se hablaba abiertamente de "fracaso» cuando la asistencia y el número de comuniones eran inferiores a los que se podían producir con motivo de algún otro acontecimiento religioso extraordinario, como podían ser las fiestas patronales. Se consideraba también un «fracaso» el que la misión no lograse alterar la dinámica religiosa habitual de la localidad en que se llevaba a cabo, de manera que asistiesen únicamente los que acudían todos los domingos a misa, no produciéndose ningún acercamiento por parte de personas que, con anterioridad a la llegada de los misioneros, hubiesen estado apartadas.

A diferencia de lo que ocurría con las «misiones triunfalistas», e incluso con las "consoladoras», los relatos de misiones que se saldaban con un fracaso no solían incluir muchos detalles. Con todo, podemos encontrar testimonios. Así, en 1950 el Asesor Eclesiástico Provincial de Sindicatos de Cuenca se dirigía a las oficinas centrales de la Asesoría en Madrid para señalar que la misión llevada a cabo en las localidades cercanas al Pantano de Buendía se había saldado con un número ínfimo de comuniones:

Acabo de cambiar impresiones con el Sr. Obispo y con el Párroco de Buendía, uno de los pueblos que mayor contingente de obreros da al Pantano de Buendía o Entrepeñas. Impresiones que, como ya conocerá, no pueden ser más desilusionantes, ya que, según

\footnotetext{
114 AGA, AES, 1959, Caja 21
}

115 Boletín de Información..., no 7, 1951. 
me dicen, el último día apenas si comulgaron setenta personas entre hombres, mujeres y niños. [...] Yo no sé lo que habrá pasado, pero tanto el Párroco, como el Sr. Obispo, han sentido enormemente el fracaso de la citada Misión... ${ }^{116}$

«Misión triunfalista», «consoladora» o «fracasada» eran categorías mediante las cuales se pretendía evaluar si una determinada campaña misional había logrado sus objetivos. Sin embargo, ante cada una de las misiones, dentro de cada uno de los pueblos o ciudades misionados, se desplegaba una gran variedad de actitudes, a menudo contradictorias y de gran complejidad. En ocasiones, se ha presentado a las misiones como "manifestaciones genuinas de la fe popular» que contaban con un consenso casi absoluto. En el extremo opuesto, hay quien ha querido ver en ellas una especie de "pesadilla» a la que la población era sometida periódicamente por parte del estamento eclesiástico. Ambas visiones resultan simplificadoras. La misión constituía un evento extraordinario, de gran impacto sobre el espacio público, lo cual hacía que fuesen pocos los que se mantuvieran indiferentes ante ella. Las respuestas podían ir desde el entusiasmo hasta la animadversión más absolutos, pero podían incluir también numerosos posicionamientos intermedios.

Como es lógico, las personas que más intensamente respondían a la movilización misional eran aquellas que poseían fuertes convicciones religiosas. Para ellas se trataba de un momento de apoteosis destinado a realizar una manifestación pública de su fe. La misión creaba un ambiente de excitación religiosa que comenzaba a configurarse ya desde los días previos a la misma, a través de la realización de acciones de propaganda y convocatorias a «cruzadas de oración» mediante las cuales se incitaba a los fieles a rezar por el éxito de los misioneros. El compromiso era especialmente intenso entre aquellos que formaban parte de asociaciones de seglares, a las cuales solía atribuírseles diferentes tareas de apoyo a la labor de los misioneros.

Al mismo tiempo, las misiones podían dar lugar a casos de revitalización religiosa o, incluso, de conversión. Numerosas crónicas misionales ofrecen testimonios de personas que habían vivido apartadas de la Iglesia durante años y que, sobrecogidas por el ambiente generado durante las mismas, pedían ser oídas en confesión. Las «misiones triunfalistas», y a veces también las "consoladoras», solían arrojar reacciones de este tipo, las cuales entusiasmaban a los misioneros, quienes veían en ellas la confirmación de que su apostolado servía al fin que se había propuesto: recristianizar a aquellos sectores de la sociedad que se habían apartado de la Iglesia.

No debemos olvidar que las misiones poseían también un indudable componente festivo, especialmente para niños y jóvenes. La misión incorporaba una serie de actos específicamente dirigidos a los niños (la «misión infantil») que implicaban el que éstos abandonasen la monotonía del horario escolar para realizar actividades en plena calle, tales como procesionar realizando cánticos religiosos y agitando "banderitas» o representar breves piezas teatrales de contenido religioso. Dicho ambiente festivo se trasladaba también a los jóvenes quienes, por iniciativa propia o por indicación de los misioneros, se convertían a menudo en auxiliares de éstos, función que realizaban en un ambiente que combinaba el deseo de ayudar con el de divertirse. Por ejemplo, durante la misión celebrada en 1955 en Villarluengo (Teruel) dos grupos de jóvenes, separados por sexos, se ocuparon de hacer de "despertadores» del vecindario para que éste acudiese al rosario de la aurora. A las cuatro de la mañana recorrían las calles del pueblo cantando alboradas y jotas. Pronto surgió una "competición» entre chicos y chicas para determinar cuál de los dos grupos cantaba más fuerte. ${ }^{117}$ En una sociedad que estaba aún lejos de disfrutar de las posibilidades de ocio características del consumo de masas, los días de misión suponían para los jóvenes una válvula de escape y una oportunidad para divertirse.

Pero junto con aquellas personas que percibían la misión como un acontecimiento positivo, también había quienes lo vivían como una experiencia negativa. Quienes habían asimilado los planteamientos laicistas y anticlericales promovidos por la experiencia republicana tendían a ver en la misión una manifestación triunfalista de la victoria del "orden clerical» contra el cual se habían posicionado. Como hemos explicado, muchos de ellos veían en la organización de misiones motivaciones políticas y se mostraban convencidos de que el régimen franquista y la jerarquía eclesiástica coordinaban sus actuaciones en aras de defender intereses comunes. Finalmente, la reiteración de las misiones, que en algunas localidades se desarrollaban cada tres o cuatro años, debió provocar también fenómenos de hartazgo por parte de personas que no practicaban la religión católica y que, a través de las constantes visitas de los misioneros, habrían terminado sintiéndose «acosadas» por los mismos.

Indudablemente, entre quienes percibían la misión en términos positivos y quienes lo hacían en términos negativos existía toda una gama de posiciones intermedias. Había quien disfrutaba con el colorido de la misión infantil pero evitaba acudir a los actos generales porque no tenía intención de confesarse. Y había quien acudía fervorosamente a la procesión de la patrona pero ponía excusas para no asistir a las conferencias doctrinales, dado que éstas le resultaban aburridas. Había también quien permanecía indiferente ante la misión. No acudía a sus actos, pero tampoco los percibía de una manera hostil. Se trata de una actitud que debió ir ganando fuerza durante la década de 1960, cuando el proceso de conformación de una sociedad de consumo de masas comenzó a generar formas de ocio y diversión que, a menudo, actuaban como alternativas a los actos religiosos.

El ideal de los misioneros consistía en que la dinámica de la «misión triunfalista» se reprodujese en todas y cada una de las misiones que llevaban a cabo. Sin embargo, eran conscientes de que ello no era posible. Los índices de práctica religiosa presentaban puntos de partida muy diferentes en las distintas regiones españolas y, al mismo tiempo, dichos puntos de partida condicionaban en gran medida los resultados de las misiones. Desde comienzos del siglo XX la sociología religiosa venía constatando la existencia en España de un mapa religioso marcado por una fuerte dicotomía. Existía una España con altos índices de práctica religiosa y que coincidía, con la excepción de Cataluña, con la España septentrional. Y existía una España meridional en

\footnotetext{
116 AGA, AES, 1950, Caja 26.
}

117 Boletín de Información..., no 26, 1956. 
TABLA 5

Datos de asistencia en seis campañas misionales llevadas a cabo por la Asesoría Eclesiástica de Sindicatos

\begin{tabular}{|c|c|c|c|c|c|}
\hline Campaña misional & Fecha & Población misionada & Cump. dominical (\%) & Cump. pascual (\%) & Asistencia a la misión (\%) \\
\hline Cuenca minera de Palencia & 1958 & 29.509 & 81,3 & 91,4 & 89,7 \\
\hline Cuenca minera de León & 1959 & 56.506 & 77,3 & 90,1 & 95,7 \\
\hline Puertollano (Ciudad Real) & 1961 & 53.136 & 20,2 & 26,1 & 39,4 \\
\hline $\begin{array}{l}\text { Cuenca minera de Peñarroya-Pueblonuevo } \\
\text { (Córdoba) }\end{array}$ & 1964 & 35.148 & 37,5 & 44,5 & 40,5 \\
\hline Valles de los ríos Alberche y Tiétar (Ávila) & 1965 & 15.838 & 70,8 & 84,8 & 73,7 \\
\hline Tierra de Campos (Zamora) & 1967 & 11.737 & 90,2 & 93,7 & 92,9 \\
\hline
\end{tabular}

Fuente: Elaboración propia a partir de documentación del AGA.

la que los índices de práctica religiosa eran más reducidos y en la que la posición hegemónica del catolicismo como cauce espiritual de la vida en común estaba muy lejos de ser indiscutida. ${ }^{118}$ Factores históricos, económicos, sociales y culturales determinaban esta dicotomía.

En 1972 Rogelio Duocastella confirmaba esta situación al aportar datos de asistencia a la misa dominical desglosados por regiones. Las regiones con mayor índice de asistencia eran: Vasconia y Navarra (71,3\%), Castilla la Vieja y León (65,3\%), Aragón (61,2\%), Baleares (58,3\%) y Galicia y Asturias (40,8\%). Mientras que las que presentaban índices más bajos eran: Valencia y Murcia (30,2\%), Extremadura $(26,7 \%)$, Andalucía $(22,4 \%)$, Canarias $(22,4 \%)$, Cataluña $(21,7 \%)$ y Castilla la Nueva $(17,6 \%) .{ }^{119}$

El punto de partida de la práctica religiosa en el ámbito geográfico en que se iba a llevar a cabo la misión determinaba, en gran medida, el resultado de la misma. En las regiones que presentaban los índices más altos de práctica religiosa, como por ejemplo en Castilla la Vieja y León, el éxito de la misión se daba por descontado. Por el contrario, en Andalucía o Extremadura las «misiones triunfalistas» escaseaban y una «misión consoladora» era considerada como un buen resultado.

Gracias al afán de la Asesoría por contabilizar el número de asistentes a los actos misionales y el número de comuniones distribuidas entre los mismos disponemos de un banco de datos cuantitativos que nos permite abordar la cuestión de cuál era realmente el impacto social de las misiones. La utilización de dichos datos plantea, sin embargo, no pocos problemas. En primer lugar, los misioneros de la Asesoría no siempre fueron rigurosos a la hora de contabilizar las comuniones y la asistencia. El interés por elaborar estadísticas precisas no apareció hasta finales de la década de 1950, coincidiendo con la asimilación por parte de los misioneros de las técnicas sociológicas que sus homólogos franceses venían desarrollando desde comienzos de la década. A pesar de ello, fueron numerosas las campañas misionales celebradas durante las década de 1960 y comienzos de la de 1970 en las que no se realizaron recuentos sistemáticos de comulgantes y asistentes, continuándose con el sistema de apreciación cualitativa que había dominado con anterioridad.

Otra cuestión que plantea dudas es la de la fiabilidad de los datos aportados. ¿Hasta qué punto debemos creer en la

\footnotetext{
118 Lannon 1990: 25 y ss.

119 Duocastella 1975: 129-162.
}

capacidad de los misioneros para contabilizar con exactitud el número de personas que asistían a los actos misionales y comulgaban durante los mismos? Ciertamente, resulta creíble que los misioneros y sus colaboradores fuesen capaces de identificar a los asistentes en localidades que contaban con un número reducido de habitantes. Pero en las que contaban con varios miles tenemos derecho a poner en entredicho la fiabilidad de los datos aportados. Por todo ello, nos inclinamos a considerar las cifras como informaciones indicativas del impacto de las misiones. A través de ellas obtenemos una visión cuantificada de la percepción que los misioneros poseían acerca del poder de convocatoria que habían alcanzado.

En la Tabla 5 presentamos los datos de asistencia los actos organizados en cinco campañas misionales celebradas entre 1958 y 1967 y, al mismo tiempo, los comparamos con los datos de cumplimiento dominical y pascual que presentaban las áreas misionadas, siempre según estimaciones de los párrocos. Hemos optado por reflejar los datos de asistencia y no los de comuniones distribuidas debido a que estos últimos presentan mayores problemas de fiabilidad. En el transcurso de cada misión los asistentes disponían de diversas ocasiones para comulgar, siendo numerosos los que lo hacían en varias ocasiones. En muchos casos parece evidente que se contabilizaron como varios comulgantes lo que, en realidad, eran diferentes comuniones de una misma persona. Por el contrario, los recuentos de asistentes a los actos misionales solían ir acompañados de una indicación del porcentaje que los mismos suponían sobre la población misionada, lo cual nos indica una voluntad clara de expresar el impacto que la misión había alcanzado.

Entre las seis campañas misionales contempladas, podemos individuar cuatro que responden al modelo de «misión triunfalista»: las de Palencia, León, Ávila y Zamora. Significativamente, las cuatro se produjeron en zonas donde los índices de práctica religiosa eran muy altos antes de la llegada de los misioneros. Se trataba de zonas donde acudir a misa los domingos y comulgar al menos una vez año constituían prácticas arraigadas entre la inmensa mayoría de la población y donde el catolicismo conservaba su condición de cultura dominante. En estas cuatro campañas la asistencia a los actos misionales fue superior a la asistencia a misa que se verificaba en un domingo normal, lo cual nos indica que los misioneros consiguieron movilizar incluso a un sector de la población cuyo compromiso con la Iglesia no era tan intenso como el de la mayoría de sus convecinos. 
Sin embargo, con la excepción del caso de León, el número de los que asistieron a la misión fue algo inferior al de los que comulgaban en Pascua. Los misioneros explicaban este hecho debido a que parte de la población masculina del mundo rural castellano consideraba que estaba obligada a comulgar una vez al año, durante el período pascual, no teniendo que volver a hacerlo hasta el año siguiente. Si la misión se producía antes de Pascua, estas personas argumentaban que aún no estaban obligadas a comulgar porque "todavía no era Pascua» y si se llevaba a cabo una vez pasada la Pascua, argumentaban que no tenían que comulgar porque "ya lo habían hecho en Pascua». ${ }^{120}$

La campaña misional llevada a cabo en Puertollano en 1961 respondió a los cánones de la «misión consoladora». De entrada, los niveles de práctica religiosa de esta localidad manchega eran bajísimos, posiblemente entre los más bajos de España. Menos de la cuarta parte de la población iba a misa los domingos y poco más de la misma comulgaba por Pascua. Frente a estos paupérrimos datos, la misión consiguió movilizar a casi el $40 \%$ de la población, prácticamente el doble de los que acudían a misa los domingos. Se trataba de un resultado meritorio, habida cuenta del endeble punto de partida. Indudablemente, parte de este éxito fue achacable a la organización de actos específicos para obreros que se llevaron a cabo en los centros de trabajo. Antes del inicio de la misión, la Asesoría elaboró, con ayuda de los datos que le proporcionaba la Organización Sindical, un censo obrero de Puertollano, lo cual le permitió identificar cuáles eran las empresas con más empleados - particularmente la Empresa Nacional Calvo Sotelo y la Sociedad Minera y Metalúrgica de Peñarroya-, en las cuales habrían de llevarse a cabo actos misionales específicos. ${ }^{121}$

Los misioneros eran conscientes de que la «misión consoladora» no suponía una recatolización de la localidad donde se producía, pero se mostraban esperanzados en que fuese un punto de inflexión que marcase el final de un largo proceso histórico de erosión de la posición social de la Iglesia y el principio de una recuperación. La «misión consoladora» debía constituir un revulsivo que agitase la vida religiosa de la localidad misionada. Es dudoso, sin embargo, que las «misiones consoladoras» fuesen la simiente de futuras «misiones triunfalistas». De hecho, en 1950 la Asesoría Eclesiástica ya había llevado a cabo una campaña misional en Puertollano y, aunque no disponemos de datos concretos de asistencia a la misma, todo parece indicar que fue juzgada satisfactoria. Los misioneros resaltaron en su crónica que los actos para hombres debieron ser trasladados desde la Casa Sindical, donde habían sido programados inicialmente, al Cine Imperial, debido a que la primera no disponía de capacidad suficiente para acoger a todos los que deseaban asistir. ${ }^{122}$ No obstante, resulta evidente que la misión de 1950 no había supuesto una revitalización del catolicismo puertollanero, como evidenciaban los bajos índices de cumplimiento dominical y pascual de 1961.

Si la misión de Puertollano respondió al modelo "consolador», la celebrada en la cuenca minera de Peñarroya-Pueblonuevo en 1964 ejemplificó el modelo

\footnotetext{
120 AGA, AES, 1965, Caja 23-1.

121 AGA, AES, 1961, Caja 24-1.

122 Boletín de Información..., no 5, 1951.
}

de "misión fracasada». Los índices de cumplimiento dominical y pascual eran sensiblemente superiores a los de Puertollano, pero no superaban el $50 \%$ del total. La sociedad peñarriblense y la de las localidades limítrofes parecen haber estado marcadas por una acusada dicotomía religiosa entre un sector que se sentía vinculado a la Iglesia y otro que permanecía apartado de la misma, siendo este último mayoritario, pero no en términos abrumadores. Partiendo de esta situación, vemos cómo quienes asistieron a los actos misionales fueron, básicamente, los integrantes del primer sector. La asistencia a la misión fue levemente superior a la asistencia habitual a la misa dominical y levemente inferior al número de quienes comulgaban por Pascua. En definitiva, la misión no logró atraer al sector de la población que no iba nunca a la iglesia. El fracaso de esta misión fue reconocido en los informes internos de la Asesoría. ${ }^{123}$

Aunque es mucho lo que aún nos queda por saber acerca de las misiones llevadas a cabo durante el franquismo, podemos concluir que, al menos por lo que respecta a las organizadas por la Asesoría Eclesiástica de Sindicatos, las mismas no generaron una verdadera recatolización, sino que, más bien, tendieron a reforzar patrones preexistentes de conducta religiosa. En la España de altos índices de práctica religiosa, las misiones se saldaban con asistencias masivas que no hacían sino corroborar una situación preexistente de consenso social casi unánime. Por el contrario, en la "España descristianizada», donde la posición social de la Iglesia distaba de ser indiscutida, las misiones podían lograr atraer a un número significativo de los que se mostraban indiferentes (como en Puertollano) o podían limitarse a movilizar a los que habitualmente iban a misa (como en Peñarroya-Pueblonuevo), pero no daban lugar a movilizaciones unánimes como las observadas en las anteriores.

\section{CONCLUSIONES}

Aunque aún es mucho lo que nos queda por saber acerca de las misiones celebradas durante el período franquista y de su impacto religioso y social, el estudio de las llevadas a cabo por la Asesoría Eclesiástica de Sindicatos nos permite ir configurando una visión general. En primer lugar, las misiones parecen haber constituido un instrumento eficaz para extender los sacramentos del bautismo y de la primera comunión y para reducir las bolsas de población que no los había recibido. El declive del número de bautizos y primeras comuniones que se observa en las misiones llevadas a cabo durante las décadas de 1950 y 1960, en contraposición a lo ocurrido durante la década de 1940 , en la que habían sido muy frecuentes, nos indica que ésta era una problemática en vías de desaparición.

En segundo lugar, las misiones habrían contribuido a universalizar ciertos comportamientos morales preconizados por la jerarquía eclesiástica. Los misioneros mostraban un alto grado de insatisfacción con respecto

123 AGA, AES, Caja 23-1. En el Boletín de Información de la Asesoría Eclesiástica de Sindicatos se intentó enmascarar este fracaso, asegurándose que la misión había sido "apoteósica», lo que no se compadece con los datos que encontramos en la documentación de archivo: Boletín de Información..., no 61, 1964. 
al nivel de moralidad de la sociedad española, a la que concebían como corrompida por la impureza, pero lo cierto es que los datos sociológicos que manejaban no avalaban dicha visión. A mediados de la década de 1960 en la sociedad española existía un consenso generalizado en torno al modelo católico de familia, como señalan las bajas tasas de "amancebamiento» y de «ilegitimidad». Dicho consenso resultaba, además, independiente de la existencia o no de una práctica religiosa cotidiana, de manera que aquellas zonas geográficas donde la asistencia a la misa dominical no era mayoritaria no presentaban una incidencia de los comportamientos morales heterodoxos superior a aquellas donde tal asistencia resultaba masiva.

En el transcurso de la década de 1960 los misioneros, al igual que otros sectores de la Iglesia, se mostraron altamente preocupados por las consecuencias religiosas y morales de signo negativo que, a su juicio, conllevaban las transformaciones socio-económicas y culturales que estaba experimentando el país. Los misioneros adoptaron una posición defensiva ante un proceso de cambios que socavaba las bases de la sociedad tradicional. Sin embargo, una vez más, los informes socio-religiosos no confirman este pesimismo. La España de los años sesenta no aparecía como una sociedad en rápido proceso de secularización sino que, muy al contrario, mostraba una llamativa capacidad para combinar el cambio social acelerado con el mantenimiento del modelo normativo de familia católica y con unos índices de práctica religiosa que, dentro de su histórica diversidad regional, no parecían haberse resentido de una manera significativa. Ciertamente, los cambios socio-económicos experimentados en la década de 1960 estarían en la base de la secularización vertiginosa experimentada por la sociedad española desde mediados de la década de 1970, pero es interesante señalar que el efecto tardó en producirse. El mantenimiento de una Iglesia fuertemente militante, una de cuyas manifestaciones sería la persistencia del movimiento misional, constituiría una de las claves de este retraso del proceso secularizador.

Pero si las misiones pudieron constituir instrumentos eficaces a la hora de promover los sacramentos del bautismo y la primera comunión y a la hora de salvaguardar el modelo católico de familia, no podemos decir lo mismo de su utilidad a la hora de propiciar un acercamiento entre la Iglesia católica y los amplios sectores de la clase obrera que estaban afectados por la cultura del anticlericalismo. El hecho de que los actos organizados específicamente para obreros siguiesen, indefectiblemente, el modelo de «actos de empresa», en los cuales la voluntariedad de la asistencia era, cuando menos, cuestionable, revela la escasa confianza con que los misioneros afrontaban su relación con la clase trabajadora. La propia persistencia en el tiempo de actos de anticlericalismo abiertos o soterrados - la denominada "oposición a la misión», frecuentemente protagonizada por obreros - es reveladora del hecho de que persistía una relación conflictiva entre sectores destacados de la clase obrera y el hecho misional.

El fracaso de las misiones como estrategia de recatolización de la clase obrera enlaza directamente con su incapacidad para transformar de una manera definitiva el mapa religioso de España. Las misiones lograron movilizaciones masivas en regiones que presentaban una larga tradición de altos índices de práctica religiosa y donde la cultura católica resultaba ya hegemónica desde antes de la Guerra Civil. Por el contrario, en la España de bajos índices de práctica religiosa y donde la cultura católica arrastraba una tradición de cuestionamiento, las misiones oscilaron entre el modelo «consolador» y el «fracasado».

\section{BiBLIOGRAFÍA}

Alfonsi, A. 1999a. «La recatolización de los obreros en Málaga, 19371966. El nacionalcatolicismo de los obispos Santos Olivera y Herrera Oria». Historia Social 35: 119-134.

Alfonsi, A. 1999b. «La recatolización de la moral sexual en la Málaga de posguerra». Arenal. Revista de Historia de Mujeres 6-2: 365-385.

Andrés-Gallego, J. 2013. «El encuadramiento obrero en la España de 1936-1946. Propuesta de replanteamiento». La Torre de los Lujanes. Boletín de la Real Sociedad Económica Matritense de Amigos del País 60: 221-252.

Andrés-Gallego, J. y Pazos, A. M. 1999. La Iglesia en la España contemporánea /2: 1936-1999. Madrid: Encuentro.

Arbeloa, V. M. 1975. Aquella España católica. Salamanca: Sígueme.

Asesoría Eclesiástica Nacional de Sindicatos 1946. Segunda Reunión de Asesores Eclesiásticos. Memoria. Madrid: Imprenta Sindical.

Barrios Rozúa, J. M. 1999. «La legislación laica desbordada. El anticlericalismo durante la segunda república». Espacio, Tiempo y Forma, Serie V, Historia Contemporánea 12: 179-224.

Bernal García, F. 2010. El sindicalismo vertical. Burocracia, control laboral y representación de intereses en la España franquista (19361951). Madrid: Asociación de Historia Contemporánea-Centro de Estudios Políticos y Constitucionales.

Bernal García, F. 2015. «Restaurando el pueblo de Dios en la España franquista. Las misiones de la Asesoría Eclesiástica de Sindicatos, 1949-1972». Pasado y Memoria. Revista de Historia Contemporánea 14: 227-253.

Bernecker, W. L. 2009. «El cambio de mentalidad en el segundo franquismo», en N. Townson (ed.), España en cambio. El segundo franquismo, 1959-1975: 49-70. Madrid: Siglo XXI.

Berzal de la Rosa, E. 2015. "La HOAC y la asesoría de la organización sindical: dos formas de pastoral obrera», en F. Montero y J. Louzao (coords.), La restauración social católica en el primer franquismo, 1939-1953: 181-214. Alcalá de Henares: Universidad de Alcalá.

Blázquez, F. 1991. La traición de los clérigos en la España de Franco. Crónica de una intolerancia (1936-1975). Madrid: Trotta.

Brugarola, M. 1955. Sobre la catolicidad del sindicalismo español. Madrid: SIPS.

Bullón de Mendoza, A y De Diego, A. 2000. Historias orales de la Guerra Civil. Barcelona: Ariel.

Cabada Castro, M. 2015. Crónica de un encuentro-desencuentro cultural: análisis antropológico de las misiones populares jesuíticas en Galicia. Madrid: Universidad Pontificia de Comillas.

Callahan, W. J. 2002. La Iglesia católica en España (1875-2002). Barcelona: Crítica.

Callahan, W.J. 1987. "The Evangelization of Franco's New Spain». Church History 56: 491-503.

Cáritas Española. 1965. Plan C. C. B. Plan de Promoción Social, Asistencia Social y Beneficencia de la Iglesia en España. Madrid: Euramérica.

Cavalin, T. y Viet-Depaule. 2009. «Des prêtres-ouvriers au mouvement missionnaire français. Bilan historiographique et nouvelles perspectives». Histoire \& Missions Chrétiennes 9: 9-41.

Congreso. 1957. Primer Congreso de Misiones Populares. Loyola, 1956. Sevilla: Imprenta Bergali.

Congreso. 1961. Segundo Congreso de Misiones Parroquiales. Madrid 30 de junio a 5 de julio de 1958. Madrid: El Perpetuo Socorro.

Copado, B. 1973. Crónicas misionales de Andalucía. Cádiz: Imprenta Casa del Niño Jesús.

De Miguel, J. M. 1998. Estructura y cambio social en España. Madrid: Alianza. 
Del Valle, F. 1949. "La corona de espinas de Madrid». Razón y Fe. Revista Hispano-americana de Cultura 613: 99-124.

Duocastella, R. 1975. «El mapa religioso de España», en P. Almerich y otros, Cambio social y religión en España: 129-162. Barcelona: Fontanella.

Echarren Istúriz, R. 1968. "Efectos sociales queridos y no queridos en el primer Plan de Desarrollo españo|», en F. Guijarro Arrizabalaga y otros, Efectos sociales queridos y no queridos en el desarrollo español: 73-110. Madrid: Euramérica.

Ferrer Senabre, I. 2012, «Passejos, pistes i plaques: els balls a L'Horta Sud durant el primer franquisme». Quadrivium. Revista Digital de Musicología 3: 1-9.

Iribarren, J. (ed.) 1974. Documentos colectivos del Episcopado español, 1870-1974. Madrid: Biblioteca de Autores Cristianos.

Lannon, F. 1990. Privilegio, persecución y profecía. La Iglesia católica en España 1875-1975. Madrid: Alianza.

López Gallego, M. S. 2004. "La difícil relación de la Iglesia y la Organización Sindical Española durante el primer franquismo: la creación de la Asesoría Eclesiástica de Sindicatos (1944-1959)». Hispania Sacra 114: 661-686.

López García, B. 1995. Aproximación a la historia de la HOAC $1946-$ 1981. Madrid: HOAC.

López Mohedano, J. 2004. «Peñarroya-Pueblonuevo: recuerdos e historia», en Peñarroya-Pueblonuevo. A cielo abierto: 39-230. Córdoba: Cajasur.

Martín Puerta, A. 2014. El franquismo y los intelectuales: la cultura en el nacionalcatolicismo. Madrid: Encuentro.

Montero F. 2009. La Iglesia: de la colaboración a la disidencia (1956 1975). La oposición durante el franquismo /4: 123-124. Madrid: Encuentro.

Montero, F. 2002. «El impacto social de la política secularizadora republicana: la religiosidad española en 1936», en Iglesia y religiosidad en España. Historia y archivos. Actas de las V Jornadas de Castilla-La Mancha sobre Investigación en Archivos. Guadalajara 8-11 mayo 2001: 189-203. Guadalajara: ANABAD Castilla-La Mancha - Asociación de Amigos del Archivo Histórico Provincial de Guadalajara.

Montero, F. 2015. «El nacimiento de la Acción Católica especializada obrera y universitaria (1942-1956)», en F. Montero y J. Louzao (coords.), La restauración social católica en el primer franquismo, 1939-1953: 151-179. Alcalá de Henares: Universidad de Alcalá.

Moreno Seco, M. 2002. "República y actitudes religiosas. La encuesta de religiosidad de 1936», en Iglesia y religiosidad en España. Historia y archivos. Actas de las V Jornadas de Castilla-La Mancha sobre Investigación en Archivos. Guadalajara, 8-11 mayo 2001: 433-445. Guadalajara: ANABAD Castilla-La Mancha - Asociación de Amigos del Archivo Histórico Provincial de Guadalajara.

Muñoz, G. 1947. Guía para dar misiones. Barcelona: Librería Religiosa.
Murcia, A. 1995. Obreros y obispos en el franquismo. Estudio sobre el significado eclesiológico de la crisis de la Acción Católica Española. Madrid: HOAC.

Núñez, C. E. 2005. «Educación», en A. Carreras y X. Tafunell (coords.), Estadísticas históricas de España. Siglos XIX-XX: 155-244. Bilbao: Fundación BBVA.

Orensanz, A. L. 1974. Religiosidad popular española. Madrid: Editora Nacional.

Pack, S. D. 2009. La invasión pacífica. Los turistas y la España de Franco. Madrid: Turner.

Prudhomme, C. 2000. "Le grand retour de la misión?». Vingtième Siècle. Revue d'Histoire 66: 119-132.

Redondo, G. 1999. Política, cultura y sociedad en la España de Franco, 1939-1975. La configuración del Estado español, nacional y católico (1939-1947). Pamplona: EUNSA.

Regueillet, A-G. 2004. "Norma sexual y comportamientos cotidianos en los diez primeros años del franquismo: noviazgo y sexualidad». Hispania. Revista Española de Historia 218: 1027-1042.

Requena, M. 2008. «Religión y sociedad: la secularización de la sociedad española», en J. J. González y M. Requena (eds.), Tres décadas de cambio social en España: 319-343. Madrid: Alianza.

Rodríguez Lago, J. R. 2004. La Iglesia en la Galicia del franquismo. Clero secular, Acción Católica y Nacional-catolicismo. Edicions do Castro: La Coruña.

Rodríguez Ocaña, E., Ignaciuk, A. y Ortiz Gómez, T. 2012. «Ovulostáticos y anticonceptivos. El conocimiento médico sobre 'la píldora' en España durante el franquismo y la transición democrática (19401979)». Dynamis: Acta hispanica ad medicinae scientiarumque historiam illustrandam 32 (2): 467-494.

Ruiz Sánchez, J. L. 1998. «Cien años de propaganda católica: las misiones parroquiales en la archidiócesis hispalense (1848-1952)». Hispania Sacra 101: 275-326.

Secretariado Nacional del Clero. 1971. Asamblea Conjunta ObisposSacerdotes. Historia de la Asamblea. Discursos. Texto íntegro de todas las ponencias. Proposiciones. Conclusiones. Apéndices. Madrid: Biblioteca de Autores Cristianos.

Urbina, F. 1977. «Formas de vida de la Iglesia en España: 1939-1975», en R. Belda y otros (eds.), Iglesia y sociedad en España 1939/1975: 11-20. Madrid: Editorial Popular.

Vázquez, J. M. 1965. «Sociología religiosa de las migraciones interiores», en Problemas de los movimientos de población en España: 156-180. Madrid: Centro de Estudios Sociales de la Santa Cruz del Valle de los Caídos.

Vázquez, J. M. 1967. Realidades socio-religiosas de España. Madrid: Editora Nacional.

Verdoy Herranz, A. 2015. «Las misiones populares en vísperas del Vaticano II: entre la continuidad y el cambio», en F. Montero y J. Louzao (coords.), La restauración social católica en el primer franquismo, 1939-1953: 99-113. Alcalá de Henares: Universidad de Alcalá. 